Artículos

\title{
[ARTÍCULO RETRACTADO]La cruz mexicana del siglo XVI de la catedral de Palencia (España): La visión indígena del Gólgota como la "montaña sagrada"
}

\section{[RETRACTED ARTICLE]The Mexican Sixteenth-century Cross in the Cathedral of Palencia (Spain): the Indigenous Vision of Golgotha as the "Sacred Mountain"}

Ana García Barrios* y Manuel Parada López de Corselas**

Este artículo se retiró por decisión del Consejo editorial

García Barrios, Ana, \& Parada López de Corselas, Manuel. (2014). La cruz mexicana del siglo XVI de la catedral de Palencia (España): La visión indígena del Gólgota como la "montaña sagrada". Anales del Instituto de Investigaciones Estéticas, 36(105), 127-184. 


\author{
ANA GARCÍA BARRIOS \\ MANUEL PARADA LÓPEZ DE CORSELAS \\ UNIVERSIDAD REY JUAN CARLOS/UNIVERSIDAD DE BOLONIA \\ E INSTITUTO CATALÁN DE ARQUEOLOGía CLÁSICA
}

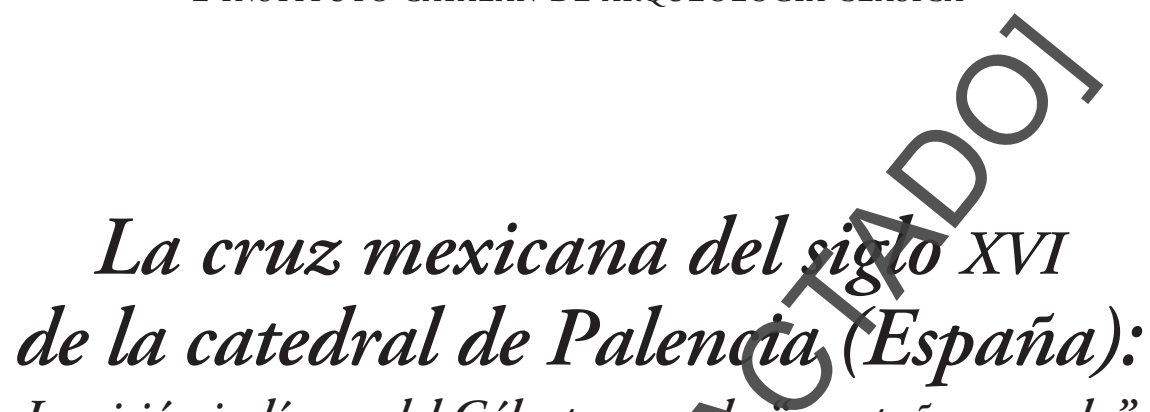
La visión indígena del Gólgota comot -montaña sagrada"

E 1 estudio de la cruz que se pres nt aquí se realiza desde una perspectiva interdisciplinar que pern ite contextualizar la obra dentro del panorama general histórico-artístico del momento y explicar su iconografía. Destacamos su carácter excep iona en relación con las piezas de platería llegadas hasta nosotros, pues es únicad conservar como base la representación en tres dimensiones de una raña sagrada mesoamericana. Por ello, se trata de una aportación novedos par el estudio del arte indocristiano, cuya bibliografía se ha restringido a a pintura, la escultura, la arquitectura o la plumaria.

La explicacion de la iconografía presente en la base de la cruz —el Gólgota transformaco en "montańa mesoamericana" habitada por numerosos animales y plantac es l punto central de este trabajo. De tal modo, se presenta la problemá ca de ła cosmovisión prehispánica y su imaginario, utilizada en esta obra cris ananalizando los recursos iconográficos empleados y preguntándonos a cerc de su posible discurso. Con ello, por medio de esta pieza apuntamos una reconsideración del arte indocristiano desde el concepto. Asimismo, contribuimos con otros pormenores inéditos de la cruz, e intentaremos encontrar explicación a su presencia en la catedral palentina. 
DOI: http://dx.doi.org/10.22201/iie.18703062e.2014.105.2530

\section{Estudios sobre la cruz de Palencia}

La cruz de altar mexicana de la catedral de Palencia, realizada en plata dorada y cristal de roca (figs. Ia y b), no ha recibido una atención especial, ni en libros y guías de la catedral como tampoco en estudios de platería más o menos específicos. La primera mención conocida ubica a la obra en la capilla del monunen to de la catedral de Palencia y la describe como "cruz de cristal horou, con imagen de santos y en la peana varios reptiles entrelazados sobre cuat o caballos con alas, época barroca, siglo XviI". ${ }^{I}$ Esta descripción se co pretatanos después: "cruz de altar realizada en cristal de roca. Los braz s de a cruz son de gran finura y rematan en plata trabajada con labor de filigrana. La peana es muy voluminosa, realizada en madera y plata; lleva i náge es de santos sobre una base de reptiles entrelazados que se apoyan en abahios alados. Finales del siglo XVII. Altura $0.48 \mathrm{mts}$. Catedral de Palencia” 2 mo vemos, se precisa que es una cruz de altar; se retrasa aún más la cronogra permanece la ambigua mención a santos (¡tal vez a la Virgen y a sar (uan los pies del Calvario, fijados cada uno a tres de los grandes agujeros la pare frontal de la base?); se incluye una descripción confusa de la fauna q la decora y una extraña mención de que la base es de madera y plata (conentro que no vuelve a repetirse en el resto de la bibliografía); y se aporta la altura aproximada; la misma que siempre se ha repetido (la medida exacta $540 \mathrm{~cm}$ ). En el siguiente estudio donde figura la cruz persiste la datación en a sig $\mathrm{xviI}$ y se propone que la peana sea de factura alemana del siglo $\mathrm{x}$

Tras estas aportaciones ny nmas, Cristina Esteras Martín realiza una serie de estudios cada vez ḿ́s anbiciosos. Es la primera investigadora en identificar la cruz de Palencia co no o ra mexicana, para lo cual se apoya fundamentalmente en el marcaj, au que también en el estilo y en la flora y fauna representadas. Reconoce marca de localidad de la ciudad de México y señala que aparece cratro veces en el borde del pie, ${ }^{4}$ aunque años después la observa sola-

I. esús an Martín Payo, Guía del museo y de la catedral de Palencia (Palencia: Diputación de Palensia, 1967), 27.

2. María Oolores Antigüedad del Castillo-Olivares, "Orfebrería religiosa en Palencia (capital)", Publicaciones de la Institución Tello Téllez de Meneses, núm. 37 (I976): I37.

3. Alejandro Fernández, Rafael Munoa et al., Enciclopedia de la plata española y virreinal americana (Madrid: Torreangulo Arte Grijalbo, 1985), 478.

4. Dato repetido en Cristina Esteras Martín, "Plata labrada mexicana en Espańa: del Renacimiento al neoclasicismo", en México en el mundo de las colecciones de arte: Nueva España, 

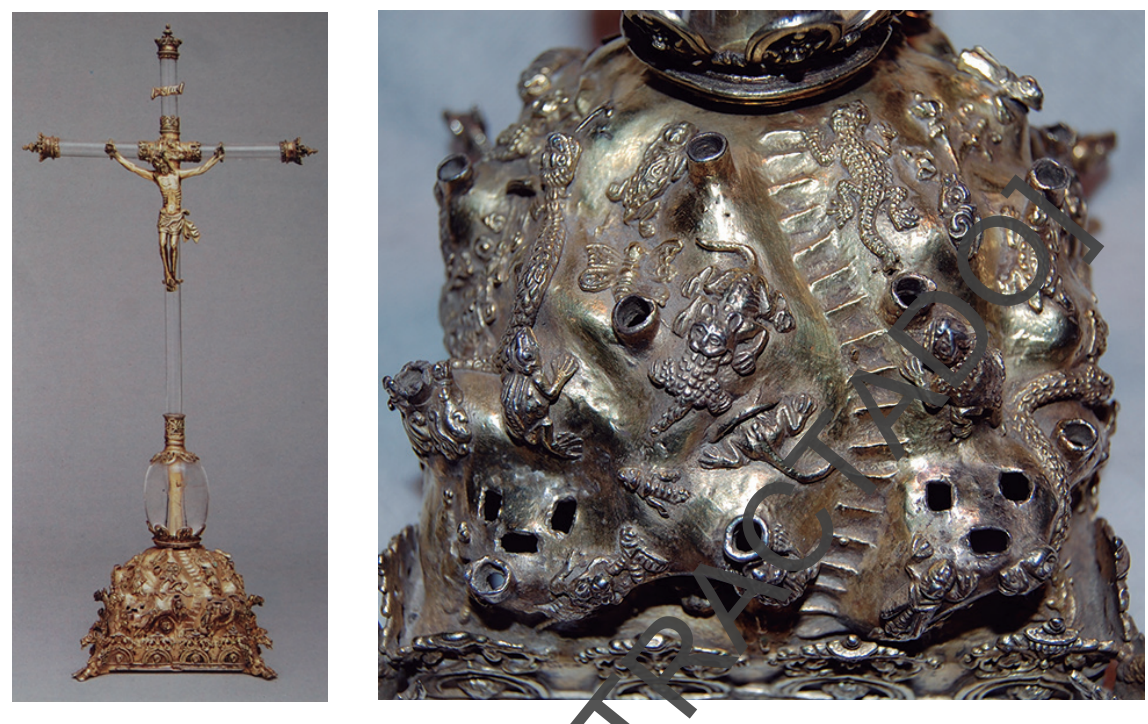

ra) Cruz de altar mexicana de la catedral de Ptencia, omada de Esteras Martín, "Platería virreinal novohispana" (vid infra n. 9, cat. 5); de 1le frontal y cenital de su base con montaña mesoamericana que sustituye al Monte Gólgo a.

mente tres veces, 5 que es lo correto. Esta misma estudiosa también publica por primera vez una fotografía dula marca presente en la cruz de Palencia, concretamente la del lateralizquiedo. ${ }^{6}$ Para la obra propone una datación cercana a I560 apoyándose en las gincidencias formales y de marcaje con la cruz de Frevol. 2 (México Az bach I994), 50, donde se dice que se trata de la variante utilizada $c a$. I560 caracterizada por arco conopial de la corona vegetal; Orfebrería hispanoamericana. Siglos XVI-XIX. Ob as viles y religiosas en templos, museos y colecciones españolas (Madrid: Museo de América/ingtituto de Cooperación Iberoamericana, 1984), 25.

5. Ch na Esteras Martín, "Altar Cross", en The Arts in Latin America I492-I820, catálogo de epericion (New Haven y Londres: Yale University Press, 2006), cat. III-8, 197.

6. ase Esteras Martín, Orfebrería hispanoamericana, 25; Marcas de platería hispanoamen ara. Siglos XVI-XX (Madrid: Tuero, I992), 6, núm. Io. Pese a ello, José Manuel Cruz Valdovinos ("Notas y precisiones sobre platerías hispanoamericanas", Boletín del Museo e Instituto Camón Aznar, núm. 28 [1987]: 40) hace una crítica a la exposición de 1986 señalando precisamente que "no se había observado marca de México en la cruz de la catedral de Palencia (núm. 3) que por desgracia no se ha expuesto”, esto pone en duda cuál de los dos notaría primero el detalle, que suponemos no figuraría en la cartela de la exposición, pero sí presente en el catálogo. 
DOI: http://dx.doi.org/10.22201/iie.18703062e.2014.105.2530

genal de la Sierra (fig. 2a) y el sahumador del Instituto Valencia de Don Juan.7 Datación similar (ca. I560-I570) se ha sugerido para otras importantes piezas mexicanas relacionadas con la cruz de Palencia, como la cruz de altar del convento de San Francisco de Cuzco, ${ }^{8}$ el cáliz del County Museum de Los Ángeles y una interesantísima cruz de altar con calavera de cristal de roca en labase, perteneciente a una colección privada mexicana (fig. 2b). ${ }^{9}$

En consecuencia, gracias a la labor desempeñada por Esteras Merni, 1 cruz de Palencia se introdujo poco a poco en el estudio general de la platería mexicana del siglo XVI en importantes obras con carácter antológico Crorras de alta divulgación. ${ }^{\text {Io }}$ Sorprende, no obstante, que en algunos co os hya perdurado

7. Esteras Martín, Orfebrería hispanoamericana, 25; Marcas de phtería hispanoamericana, 6, núms. 9-і I.

8. Cristina Esteras Martín, México en la Baja Extremadura 5 platería, Serie Memorias de la Real Academia de Extremadura de las Letras y las Arof, t. I I (Trujillo: Real Academia de Extremadura, I983), núm. I.

9. La estudiosa se preguntaba si el uso del crista te rocansería una característica de la platería mexicana de mediados del siglo xvi, si a las cruces ludidas se suma el cáliz del County Museum de Los Ángeles (Cristina Esteras Mr tín, Platería hispanoamericana. Siglos XVI-XIX. Exposición diocesana badajocense, catálogo a a osición [Badajoz: Sala Capitular de la S. I. de Badajoz, 8-I5 junio, I984] (Badajoz. Cra ace Ahorros de Badajos, 1984), 2I); idea reiterada y ya asumida en Esteras Martín, "Platen virreinal novohispana. Siglos XVI-XIX", en El arte de la platería mexicana 500 año (I90-1990), catálogo de la exposición (México: Centro Cultural Arte Contemporáneo/Fundaciól Televisa, 1989), 8I; sobre este cáliz véase Esteras Martín, "Altar Cross" y "Cruz de altar", en Revelaciones. Las artes en América Latina I492I820, catálogo de la exposicion IM Ico: Antiguo Colegio de San Ildefonso] (México: Fondo de Cultura Económica, 20 z), ca. III-4 y un portapaz perteneciente a una colección privada (Esteras Martín, Marc de planería hispanoamericana, I9, fig. 8; Esteras Martín "Altar Cross" y "Cruz de altar", (at. (U-3). A este elenco de obras vinculadas entre sí por su estilo, materiales, marca y cron log la estudiosa ańade una cruz de altar perteneciente a una colección privada mexicaua (n 1970 formaba parte de la Colección Redo), que luce una calavera de cristal de rog a quiza azteca - en su peana. Considera a esta última cruz un claro ejemplo de arte indo ristiano y le asigna la misma cronología que al cáliz de Los Ángeles (I575-I578) por su ex marca, en la que, no obstante, no se distingue si el perfil es izquierdo o dereche(Es ras Martín, Platería virreinal novohispana, I57).

ıo. Qistrna Esteras Martín, "Notas para el estudio de la platería de Castilla, Portugal y México. Siglos xvi y xvir", en Relaciones artísticas entre la Peninsula Ibérica y América. Actas del $V$ Simposio Hispano-Portugués de Historia del Arte (I I-I3 mayo 1989) (Valladolid: Universidad de Valladolid/Junta de Castilla y León/Sociedad Estatal para la Ejecución de Programas del V Centenario, 1990), 95; Rafael Martínez González, "Cruz de altar”, en Arte americanista en Castilla y León, catálogo de la exposición, cat. 6.24 [Valladolid: Iglesia de la Magdalena, II noviembre-I I diciembre I992] (Junta de Castilla y León/Consejería de Cultura y Turismo), 


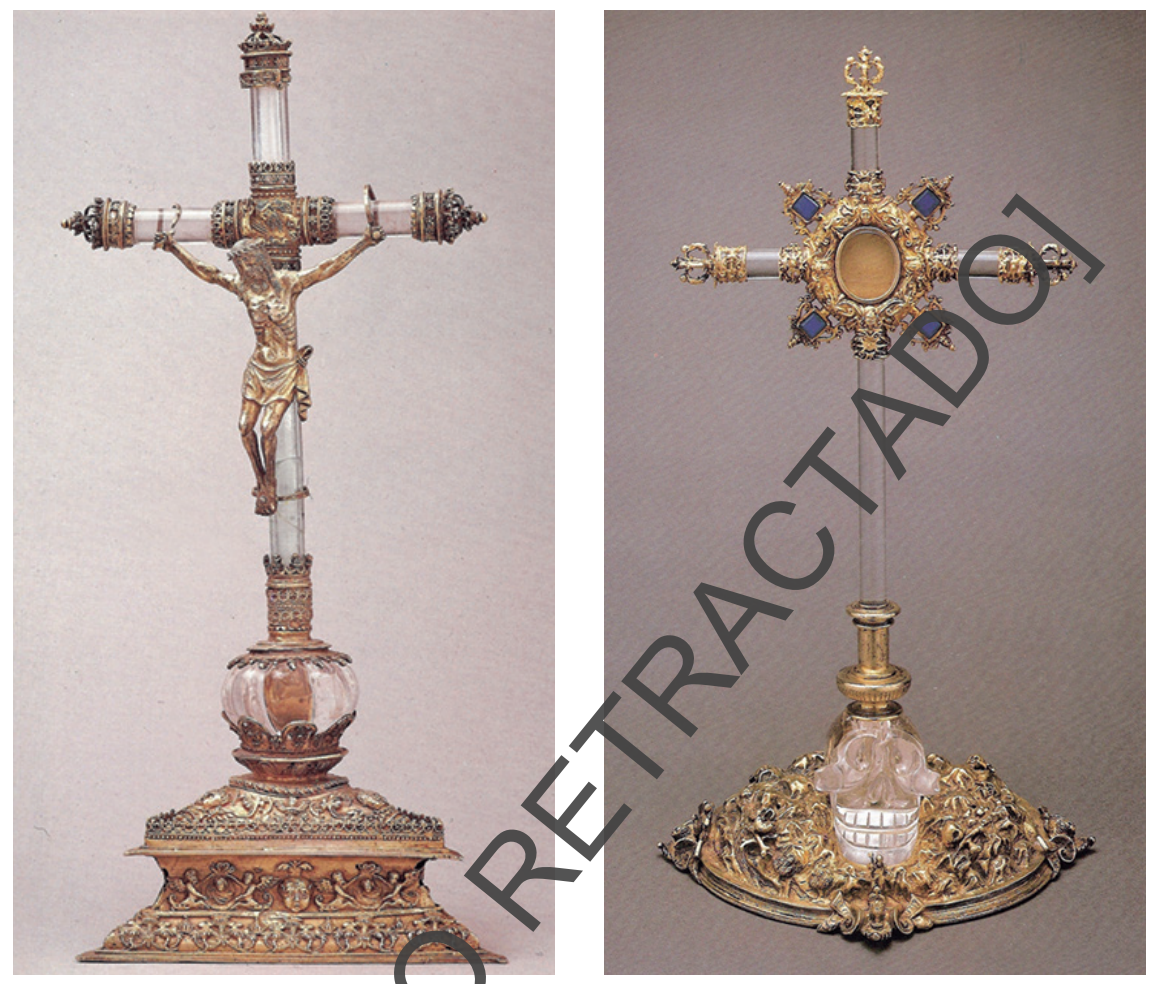

2a) Cruz de altar mexicana de Fregenal de la Sierra, tomada de Esteras Martín, Marcas de platería (vid supra n. 6, cat. 4); b) chr-Nico fo de altar mexicana, tomada de Esteras Martín, Marcas de platería (vid supra n. 6, ca r6). México, colección particular (antiguamente en la Colección Redo). I85-186; Cristiha Ctera Martín, "La platería mexicana en España: arte, devoción y triunfo social”, Artes e M.rico, núm. 22 (núm. extraordinario) (I993-I994): 4I y 43; Cristina Esteras Martín, "Plata abrada mexicana en España: del Renacimiento al neoclasicismo", en México en el mu ao de las colecciones de arte: Nueva España, vol. 2, 46 y 50-5 I —errata en la que se intercan bon fas fotos de la cruz de Palencia y de Fregenal de la Sierra-; Antonio Sancho Canpatedral de Palencia. Un lecho de catedrales (León: Edilesa, 1996), 70 y 72; J sé Carlos Brasas Egido, "Anónimo alemán. Cruz de altar", en Las edades del hombre. Memaras y esplendores, cartas de exposición (Palencia: Catedral de Palencia, I9I I); Cristina Esteras Martín, "La platería hispanoamericana: arte y tradición cultural”, en Historia del arte iberoamericano, eds. Ramón Gutiérrez y Rodrigo Gutiérrez Viñuales (Barcelona: Lunwerg, 2000), I22-I23; Cristina Esteras Martín, "Presencia de América en España. El legado artístico en la época de los Austrias", en El mundo de Carlos V. De la España medieval al Siglo de Oro, catálogo de la exposición [México: Antiguo Colegio de San Ildefonso, 3 noviembre 200025 febrero 200I] (Madrid: Sociedad Estatal para la Conmemoración de los Centenarios de 
DOI: http://dx.doi.org/10.22201/iie.18703062e.2014.105.2530

I32 GARCía barRios - PARAda López de CORSElas

la datación del siglo XVIII ${ }^{11}$ y la atribución alemana. ${ }^{\mathrm{I2}}$ Pese a la amplia presencia en diversas publicaciones, entre las cuales la más significativa por su alcance científico y resonancia internacional fue la exposición "The Arts in Latin America I492-I820/Revelaciones. Las artes en América Latina I492-I820”, I3 que se exhibió en Filadelfia, Los Ángeles y en la ciudad de México, las menciones al carácter indocristiano de la cruz de Palencia han sido tímidas o h n te ide poco alcance y se ha titubeado a la hora de definir su programa icgmoracico. ${ }^{14}$

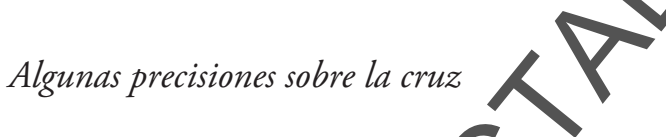

La obra, objeto de este estudio, es una cruz de altar, ${ }^{\mathrm{I}}$ tipo ogía de mobiliario litúrgico desarrollada desde la Edad Media y que gaéndegran éxito en el Rena-

Felipe II y Carlos V, 2000), 392; Esteras Martín, "Alta Cross"; Esteras Martín, "Cruz de altar"; Juan Crespo Cárdenas, Plata y plateros Cudad Real, I500-I625 (Ciudad Real: Diputación Provincial de Ciudad Real, 2007), 184; Miguel Gleason, México en España [recurso audiovisual en 2 DVD-ROM], DVD 2 [en ast Cristina Esteras Martín y fotografías de la cruz de Palencia] (México: Consejo cional para la Cultura y las Artes-Dirección General de Publicaciones, 2010); La catedra Palencia. Catorce siglos de historia y arte, coord. René Jesús Payo Hernanz (Burgos: Premecal Publicaciones, 20I I), 526, 528 y 529.

II. Sancho Campo, La catedral o Pale cia. Un lecho de catedrales, 70 y 72.

I2. En el caso de Brasas Egido, "Ourde altar", 293, el hecho es especialmente curioso, ya que la pieza se incluye en la seccio "Elyiaje a las Indias". Se le asigna una cronología razonable, primer tercio del siglo Xvi, y un medidas de $48 \times 23 \mathrm{~cm}$, con base de $14.5 \mathrm{~cm}$ de ancho. Se la relaciona con Núremberg or "compleja y rica decoración animalística", comparándola con la escribanía atribu ida a Wenzel Jamnitzer y conservada en el Kunsthistorisches Museum de Viena, posiblemente lor lesconocimiento de la bibliografía.

I3. Esteras Mr tín, Ntar Cross" y "Cruz de altar".

I4. Esteras Marth alude a Reyes-Valerio y cita el término "indocristiano" ("Platería virreinal no oh spana", I57) o "indiocristiano" (“Altar Cross", 196). La investigadora escribe: "[la cruz de P.encia] sin perder la manera renacentista se ofrece ya como un claro ejemplo de síntesis Entro español y lo indígena" (Esteras Martín, "Plata labrada mexicana en España", 46); de mundo ancestral de los indígenas mexicanos quedan también algunos vestigios en piezas muy singulares, como la cruz [...] de Palencia" (Esteras Martín, "La platería hispanoamericana", I24). Reconoce algunos animales de la fauna local, intenta desentrañar en líneas generales el programa iconográfico y compara varios de sus motivos con el Códice Borbónico (Esteras Martín, "Cruz de altar", 20I).

I5. Altura total: $48.5 \mathrm{~cm}$. Altura desde la base de la cruz a la punta de la cruz: $39.2 \mathrm{~cm}$. Altura de la montaña: $9.3 \mathrm{~cm}$. Envergadura de la cruz: $23.8 \mathrm{~cm}$. Base con pies de pata a pata: I $4 \mathrm{~cm}$; y sin pies: $10.5 \mathrm{~cm}$. Altura de Cristo: $10.7 \mathrm{~cm}$. Envergadura de Cristo: $9.4 \mathrm{~cm}$. 
cimiento; se manufacturó para satisfacer la necesidad litúrgica de la presencia en todas las misas de la imagen de Cristo crucificado. El ejemplo que estudiamos aparentemente muestra una composición inconfundible del calvario, Jesús crucificado en el Monte Gólgota. Sin embargo, se desliga de la iconografía típica de otras obras del mismo tema al presentar una serie de características peculiares que le otorgan una particularidad única, al sustituir el Gólgota for un monte de tradición indígena, hipótesis que trataremos de demostra

Los travesańos de la cruz están realizados en cristal de roł. E modelo de Cristo sigue una iconografía también frecuente a finales dorarad Media y el Renacimiento. Jesús crucificado se muestra con los ojo abie tos antes de expirar: la cabeza caída hacia la derecha, y el cuerpo pesado queda suspendido en la cruz mediante tres clavos; dos anclan las palma (de lis manos al madero, y un tercero sujeta a los dos pies dispuestos uno spare orro. Varios elementos del Crucificado, entre ellos su anatomía y el tipo-de año de pureza, están en sintonía total con la imaginería ligera en cañ d Mraz de mediados del siglo xvi en México. ${ }^{16} \mathrm{Su}$ corona de espinas forp ada por dos ramas entrelazadas también es típica de la imaginería del monento, copiada de los grabados que llevaron los frailes a América. La inclusion de pios Padre, justo detrás de Jesús crucificado, así como la imagen de 1 Vroen María — que evidencia el dogma de la Encarnación - en la parte posterior de la cruceta, son relativamente frecuentes desde finales de la Edad Medra sobre todo en cruces parroquiales que poseen soluciones análogas. La prencla de Dios Padre recuerda las cruces trinitarias promovidas por los frantiscayos desde el siglo XIV. ${ }^{17}$ Este dato y el posible modelo de Dios Padre tomado de fachadas o estampas franciscanas refuerzan la probable vinculaciónde con dicha orden mendicante. De estos primeros momentos de cantac o existen pinturas murales donde aparece Dios Padre con Dios Hijo y el L piritu Santo coronando a la Virgen en el momento del Tránsito, como se tuen el convento de Epazoyucan, Hidalgo. ${ }^{18}$ También se hicieron 2

I6. Pa_ F. Amador Marrero, "Imaginería ligera en Oaxaca. El taller de los grandes Cristos", de Monumentos Históricos, tercera época, núm. is (enero-abril 2009): 45-60; Imagherr Iigera novohispana en el arte español de los siglos XVI-XVII. Catalogación, historia, análisis y restarración (Universidad de Las Palmas de Gran Canaria, 20I2).

17. Agradecemos los comentarios que Juan Miguel Ferrer Grenesche, subsecretario de la Congregación para el Culto Divino y la Disciplina de los Sacramentos, y Jesús Folgado García han aportado.

I8. María del Consuelo Maquívar, De lo permitido a lo prohibido. Iconografía de la Santisima Trinidad en la Nueva España (México: Instituto Nacional de Antropología e Historia/ Miguel Ángel Porrúa), 78-79. 
DOI: http://dx.doi.org/10.22201/iie.18703062e.2014.105.2530

\section{I34 GARCía BARRIOS - PARADA LÓPEZ DE CORSELAS}

esculturas con la representación de la Santísima Trinidad donde se observa a Dios Padre en la misma actitud que en la cruz de altar. ${ }^{19}$ Igualmente, era habitual la iconografía de la Asunción a los cielos de la Virgen y de su Coronación, con gran influencia en sus diseños de lo descrito en los textos apócrifos. Como explica María del Consuelo Maquívar, ${ }^{20}$ uno de estos escritos refiere como, mientras los apóstoles estaban delante del sepulcro de la Madre de D os, Cris to se apareció con el arcángel san Miguel y una legión de ángeles, sंgnemelo las instrucciones de Jesús colocaron a María sobre las nubes y así fue rasl dada al paraíso. Al entrar allí se colocó su cuerpo al lado del árbol de arda, y entonces su alma volvió a establecerse en el cuerpo. El árbol de vid es en esencia la cruz de Cristo que según las Actas de San Pedro del sigla II tayo su figuración también en el cielo. ${ }^{2 \mathrm{I}}$ Por tanto, la presencia de la Made de Jesús, junto a Dios Padre y Cristo crucificado debió formar parte de l iconografía cristiana en la que los tres habitan en el cielo. Además de que laM. are de Jesús y Dios Padre forman parte esencial de la pasión de Jesús en En la Nueva España fue muy común reproducir a las tres figuras junas en diferentes episodios de la vida de Jesús o de la Virgen.

La base de la cruz se asienta sobre una vonkaña que ejerce de figura del Monte Gólgota, lugar donde Jesús sufrió na tirio y murió. Desde entonces ese monte se convirtió en un espacio sagrado, lug de culto y peregrinación, que simboliza desde aquello el centro del mu ndo, pues en él se produjo la redención del hombre. A esta base tan peculiar, ena que el Gólgota se sustituye por la "montaña sagrada" mesoamericana a dicaremos los apartados 5 y 6 del presente trabajo.

La datación temprana y 1 rigen de la cruz de Palencia se establecen por el tipo de trabajo, por armavel de localidad y por la iconografía, especialmente la que está presente en su base. En cuanto al tipo de trabajo: se emplearon la técnica de fundicion a a cera perdida, conocida por los artífices prehispánicos, y que incluye un rotoque final a cincel $\mathrm{u}$ otros instrumentos para apurar detalles y acabado $S$ bre las piezas mayores, como la base-montaña: se utilizaron elementospequeños con multitud de detalles, como los animales. El interior de la ment a, que se mantiene como salió del molde — con aspecto granulado, rugoso X in dorar-, manifiesta además que no se utilizó el relevado o repu-

19. Maquívar, De lo permitido a lo prohibido, 90-91.

20. Maquívar, De lo permitido a lo prohibido, 90-91.

21. Jaime Lara, City, Temples, Stage. Eschatological Architecture and Liturgical Theatrics in New Spain (Indiana: University of Notre Dame Press, 2004), 158. 
jado. Los pequeños tubos que atraviesan la montaña, en cuanto a la técnica, podrían haber ayudado en el proceso de fundición, y asimismo podrían tener otra función ritual que se explicará más adelante.

Los mexicas trabajaban magistralmente la plata, el oro y el cristal de roca tallado. Aunque la combinación de dichos materiales en la misma obra corresponde más bien al gusto europeo, es característica del siglo xvi n M xico. ${ }^{22}$ Muchos son los plateros que llegan de España y que, bajo su prando control de las piezas, encargarán a los artesanos indígenas un gran número le ellas para la liturgia cristiana. Los nativos eran grandes artesanos y or ebyespor su destreza y habilidades, tal y como señalan los castellanos, y coce de adaptarse con rapidez a las nuevas herramientas en el trabajo de la plata.23 Juan José Batalla Rosado y José Luis de Rojas ${ }^{24}$ exponen que los fr giles franciscanos alababan la destreza de los plateros y orfebres indígenas de sigio xvi:

a los plateros faltábanles las herramientas a a a tubrar de martillo, pero con una piedra sobre otra hacían una taza llena d plata un plato. Con todo eso, en fundir cualquier pieza o joya de vaciadizo hacían ventaja a los plateros de España, porque funden un pájaro que se le anda la cabza/a lengua y las alas. Y vacían un mono o otro animal, que se le andan cabez nies y manos, y en las manos les ponen unos trebejos que parecen bailar con elos. Y lo que más es, sacan una pieza la mitad de oro y la otra mitad de pla y yacían un pece la mitad de las escamas de oro y la otra mitad de plata; una can de plata otra de oro, que se maravillaron mucho los plateros de Españar.s

La marca presepe en base de la cruz corresponde a la localidad de México y apareca fregmentariamente, tres veces: en la parte posterior, en el lateral izquierd y e el frente - la impronta más clara y completa de todas-, siempre en e borde de la base o próxima a él, entre los arcos conopiales que acoge cabezas infantiles (figs. 3a-d). La marca de México a la cual se corresponden stas improntas la constituyen dos columnas timbradas con arco o

23. María del Consuelo Maquívar, La escultura religiosa en la Nueva España (México: Consejo Nacional para la Cultura y las Artes, 200I), i I.

24. Juan José Batalla y Rosado y José Luis de Rojas, La religión azteca (Madrid: Trotta/ Universidad de Granada).

25. Tomado de Gerónimo de Mendieta, Historia eclesiástica indiana, citado en Esteras Martín, "Platería virreinal novohispana", 79-80. 
DOI: http://dx.doi.org/10.22201/iie.18703062e.2014.105.2530

I36 GARCÍA BARRIOS - PARADA LÓPEZ DE CORSELAS
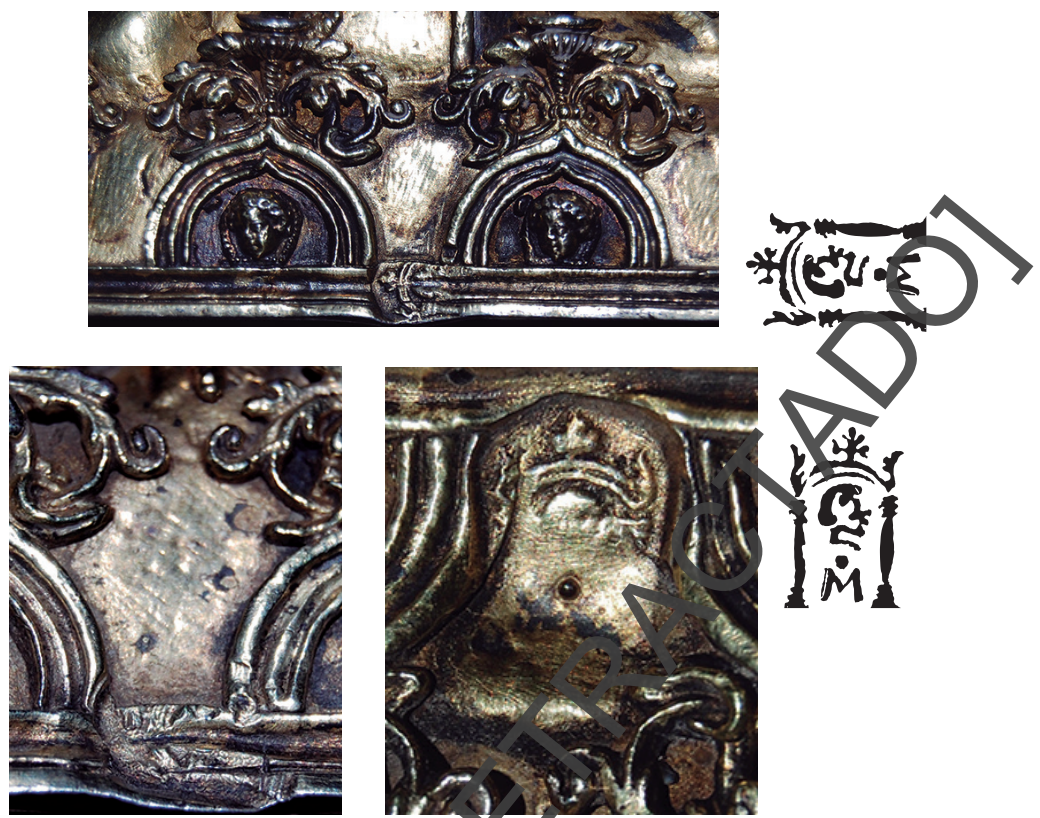

3a, b y c) Marcas de localidad de la iudau de México (mediados del siglo XVI-ca. I 572) en la cruz de altar de Alencia (respectivamente: cara posterior, lateral izquierdo y frente); d) dibujo reconstructivo de la marca con el fin de facilitar su identificación.

corona vegetal de tres punvas. Rntre las columnas y debajo de la corona se sitúa una cabeza masculina on barba y bigote, sobre una "M" que tiene un punto o una "o" encima (breviatura de México). En este caso a la cabeza se le representa de perfil decho distinguible en la marca del lateral izquierdo y en la de la cara posa aior, empleada hasta el platero A. Ońate (activo $c a$. I558-1572), pues poste 10 mente Miguel de Torres (activo ca. I559-I6IO) lo invierte. ${ }^{26} \mathrm{La}$ fecha post on em para la marca presente en la cruz de Palencia es cercana a I527I530, antrouse desconoce cuándo empieza a utilizarse exactamente; sugerimos situâ su so entre 1538 y $1572 .{ }^{27}$ Se utiliza también en el pie de la cruz-relicario

26. Fernández, Munoa et al., Enciclopedia de la plata española, 349.

27. Lawrence Anderson (The Art of the Silversmith in Mexico 1519-1936 [Nueva York: Hacker Art Books, 1975], 75-76) explica las circunstancias un tanto accidentadas de la producción en los primeros años después de la conquista de México (I52I): temor a perder el quinto real (señal de que se labraba y vendía plata); prohibición de la producción, emitida el 9 noviembre de 1526 
del lignum crucis realizada en filigrana de plata y conservada en la iglesia de San Pedro de Ciudad Real, ${ }^{28}$ y en un acetre perdido, datable entre 1546 y I55I, ${ }^{29}$

en Granada, pero proclamada en "Tenuxtitlán” el 22 de agosto de I527, aunque Gruz Valdovinos considera la prohibición "papel mojado", véase "Notas y precisiones sobre platóras hispanoamericanas", Boletín del Museo e Instituto Camón Aznar, núm. 28 (1987): 4, com in múa Anderson; problemas en ejecutar la norma; quejas y reforma de la legislación ( 5 5 L I I 522 se creó el cargo - más honorífico que efectivo- de fundidor y marcador e Méxi o, otorgado a Francisco de los Cobos, secretario de Carlos V (Heredia Moreno, "Precision sobre los cargos públicos de la platería en el Virreinato de Nueva España [I527-I650]", Dr Landios de platería. San Eloy, coord. Jesús Rivas Carmona [Universidad de Murcia, oro], 07-309). Los primeros veedores comenzarían su trabajo en 1527 (Anderson, The Art of Silversmith in Mexico I519-1936, 79) y al principio también se ocupaban de marc r, tar después transferida a los marcadores. En la misma época se crearon diversos cargos prevtos ara la supervisión y control de la plata (véanse las listas de cargos en Esteras Martín, vay de platería hispanoamericana, 93; Heredia Moreno, "Precisiones sobre los cargos pablico de la platería en el Virreinato de Nueva España (I527-I650]”, 317-318). En México 1 rarca presente en la cruz de Palencia se alterna con otra, que luce un castillo sobre un a divdido en dos por una calzada que llega hasta la puerta del castillo. A la vista de la bibliogra que manejamos (especialmente Esteras Martín, Marcas de platería hispanoameric a 105 y marcas núms. I-23; véase el catálogo de marcas en Esteras Martín "Platería virréîg no hispana”: 390-393, núms. I-I6) ambas marcas son contemporáneas, pero esta última unas veces se utiliza como marca de localidad (Esteras Martín, Marcas de platería hispanoamerica marcas núms. I y 5) y otras como marca fiscal. Tampoco queda claro cuándo co menz rían a utilizarse, aunque según Esteras Martín la primera noticia sobre la marca de Méx co es de I530 y se corresponde con el castillo lacustre (Esteras Martín, "Más noticias sobr Villasana y Consuegra, marcadores de la platería mexicana del siglo xvi", Cuadernos de Arte Con núm. 7 [mayo, I99I]: 90). Anderson señala como referencia que la abreviatura de $\mathrm{M}$ 'xico la "M" con un punto u "o" encima) se emplea en la numismática novohispana desde 1538 (Anderson, The Art of the Silversmith in Mexico 1519-1936, 287); antes se usaba la "M", so en grafía gótica o latina (real cédula de i de mayo de I535), a la que se ańadió la citada "o" poco a poco desde 1538 hasta hacerse oficial por orden virreinal del 28 de junio de ${ }_{5}{ }_{2} 2$ réase Alberto Francisco Pradeau, Numismatic History of Mexico from the PreColumbi n poch to 1823 [Los Ángeles: Western Printing, 1938], 30; Historia numismática de México. sae la época precortesiana hasta I823, trad., corregida y aumentada, Román Beltrán Mar trez (México: Banco de México, 1950], 37-38). La antigua Tenochtitlan no comienza a denon narse "México Tenuxtitlan" o simplemente México hasta cerca de 1535 como plantea la revédula citada y hacia 1536, que es cuando se hace el cambio de nombre (véase Anderson, The Art of the Silversmith in Mexico I519-1936, n. 20 infra 287).

28. Juan Crespo de Cárdenas, Plata y plateros. Ciudad Real, I500-I625 (Diputación Provincial de Ciudad Real, 2006), I04-I07, II8 y i83-I86.

29. José Manuel Cruz Valdovinos “Dos 'incunables' de la platería mexicana y varias observaciones sobre el marcaje en la capital virreinal durante los siglos XVI y Xvı", Archivo Español de Arte, núm. 237 (1987): 39-40. 
DOI: http://dx.doi.org/10.22201/iie.18703062e.2014.105.2530

I 38 GARCía BARRIOS - PARADA LÓPEZ DE CORSELAS

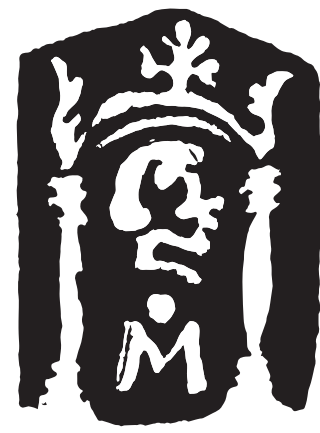

4. Para permitir una mejor identificación añadimgela mponta de la misma marca presente en la cruz de altar d cony nto de San Francisco de Cuzco, tomada de Esteras Martín, México en la Baja Extremadura (vid supra 8, pam. I).

entre otras piezas como la citada cruz de altar de Fregonde la Sierra y la de Cuzco (fig. 4) y el sahumador del Instituto Valendizae Don Juan..$^{30} \mathrm{El}$ arco cronológico en el que se han datado tradicion ment estas piezas abarca desde mediados del siglo Xvi hasta cerca de 7 , aunque las marcas no siempre tienen que haberse puesto en el momento de la realización de la obra. El año I57I es también una fecha signifi at a puesto que a partir de entonces comienza a funcionar el Santo Oficon naeva España, lo cual pudo dificultar - aunque no eliminar del todo - prácticas poco ortodoxas - como por ejemplo, la presencia de "sincretiomos" en obras de arte como la cruz de Palencia- especialmente en la ciu ad d México, lo cual coincide con acciones de control como la confiscación de los manuscritos del franciscano Sahagún..$^{31}$

Otro dato más para la datán de la cruz de Palencia lo aporta el busto de Dios Padre que se sitûa det ás de Cristo, bendiciendo con la mano derecha y sujetando la bola del myndo con la izquierda. Se trata de un modelo desarrollado especialmente $\operatorname{los}$ siglos xv y xvi. En dicho periodo se emplea abundantemente 1 Rortapaces incluido en el interior de su gablete o frontón, como sucede en ar os ejemplares conservados en el Museo Marés de Barcelona y en el Museo cional de Artes Decorativas de Madrid; este tipo de piezas permitirían s fusión. No obstante, el Dios Padre de la cruz de Palencia está abierto tahbian a otra posibilidad; sigue cánones estilísticos de influencia miguelangelesca y advierten en algunas obras de Rodrigo Gil de Hontañón — como la

30. En general, véase el repertorio de marcas de Esteras Martín, Marcas de platería hispanoamericana, marcas 2-22.

31. Serge Gruzinski, La ciudad de México. Una historia (México: Fondo de Cultura Económica, 2004), 223-224. 
portada sur de la iglesia de Santiago de Medina de Rioseco (planos ca. I533), ,32 modelo seguido en la fachada de la Universidad de Alcalá (construida entre I537 y 1553) ${ }^{33}$ y en la portada sur de San Martín en Mota del Marqués (fechada en I552). ${ }^{34}$ De hecho, el busto presente en la cruz es similar en los pliegues de la túnica, la disposición de la barba partida, el movimiento del cuerp hacia el lado derecho al levantar la mano diestra, al de Alcalá de Henares, ter himado por Juan Guerra, de Salamanca, en marzo de $1553,{ }^{35}$ quien seganmente copió este modelo o uno próximo (figs. 5a, b y c). Es bastante probable qu estos diseños y otros semejantes fechables hacia I 530 y I 550 viajasen a Arrérica para que se copiaran en tierras conquistadas. ${ }^{36}$ En este sentido hay ue se alar que Claudio de Arciniega, quien participó en la obra de Alcalá hasta 1547,37 llegó a la Nueva España hacia 1553 , donde proyectó y dirigió las obr de catedral de México. ${ }^{38}$

Podemos datar la cruz de Palencia en torno a $550-1200$, aunque sería tentador adelantar la cronología debido a la fuerza de la tradión indígena presente en ella. 32. John G. Hoag, Rodrigo Gil de Hontañón Gótico Renacimiento en la arquitectura española del siglo XVI (Madrid: Xarait Ediciones 1985),

33. Véase Pedro Navascués Palacio, "R d go Gil y los entalladores de la fachada de la Universidad de Alcalá", Archivo Españo A A 45, núm. I78 (1972): I03-I I7; Hoag, Rodrigo Gil de Hontañón, 97-99.

34. El precedente del Dios Padre está eNos retablos de la iglesia de San Francisco en Medina de Rioseco, obra de Miguel e Es. inosa de I537 que inspiraría la portada sur de la misma iglesia y la fachada de la Unive dad de Alcalá (Antonio Casaseca Casaseca, Rodrigo Gil de Hontañón (Rascafría I500 Segovia 1577) [Salamanca: Junta de Castilla y León, 1988], 247).

35. Hoag, Rodrigo Gil de Tor on, II 2, 170; Casaseca Casaseca, Rodrigo Gil de Hontañón, 246.

36. En México contan a a menos con un Dios Padre muy similar, de busto y bendiciendo, que se encuentra e â parte superior de la Inmaculada, pintada en el claustro de San Miguel de Huejotzing (N éxico), convento franciscano iniciado en I526 y concluido en I570. Otro Dios Padre may s mejante al de la cruz de Palencia tiene la misma posición en la cruz de Fregenal desa sierra y en el frontón del portapaz de plata y cristal de roca perteneciente a una colecciór P. vada, citado en la nota 9. Si prescindimos de los modelos arquitectónicos citados, y restrin i nđonos a la platería, convendría recordar un portapaz de Limoges conservado en el Mu Naconal de Artes Decorativas en Madrid (inv. CEor826) fechable en el primer tercio del si XVI y otro de Francisco Becerril antiguamente en la catedral de Cuenca (ca. I550), amss Pematados por frontón que acoge el busto de Dios Padre; tales modelos, fácilmente transportables a América, permitirían una datación más temprana de la cruz de Palencia.

37. Casaseca Casaseca, Rodrigo Gil de Hontañón, 244.

38. Hoag, Rodrigo Gil de Hontañón, I07. Para una revisión actualizada sobre Arciniega y su actividad en la Nueva Espańa véase Luis Javier Cuesta Hernández, Arquitectura del Renacimiento en Nueva España. "Claudio de Arciniega, Maestro Maior de la Yglesia Catedral de esta Ciudad de México" (México: Universidad Iberoamericana, 2009). 
DOI: http://dx.doi.org/10.22201/iie.18703062e.2014.105.2530

I4O GARCÍA BARRIOS - PARADA LÓPEZ DE CORSELAS
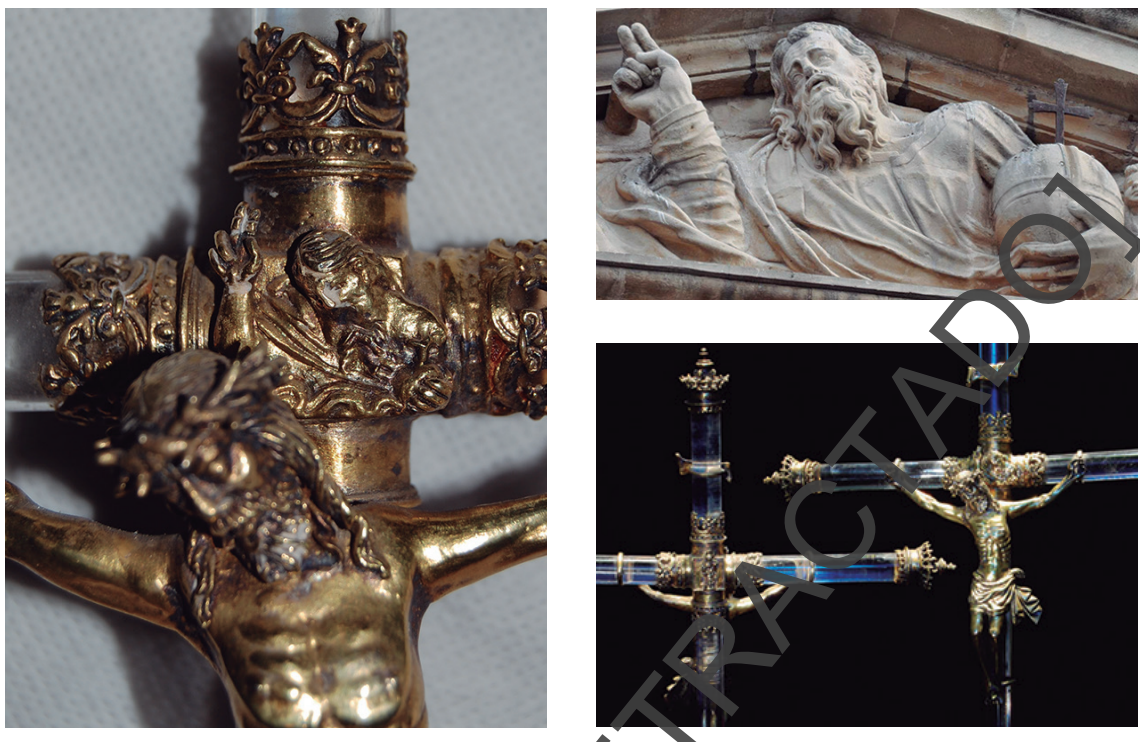

5. Detalles de la cruceta de la cruz de altar de Pa enca: a) en la cara anterior, Cristo crucificado con Dios Padre detrás; b) en la cara posterior the tomada de Gleason (vid infra n. Io); c) Dios Padre del frontón de la fachada de lca Henares realizado por Gil de Hontañón entre I 553 y I 555 .

\section{¿Cuándo llega la cruz a Palegcra?}

La bibliografía un ultada no ha podido resolver cómo y cuándo llegó a Palencia la cruz mextcan que estudiamos, ${ }^{39}$ pero esperamos que próximas investi-

39. Cristip a steras Martín, "Presencia de América en España. El legado artístico en la época de los A ustriás", en El mundo de Carlos V. De la España medieval al Siglo de Oro, 392, "no sabcroc de donantes ni de cuándo ingresaron en estos templos" (se refiere a las cruces de Palenc $y$ Fregenal). Por nuestra parte, no hemos podido encontrar una mención explícita a la crù de Palencia en ninguno de los inventarios catedralicios. Ni en el de 1667 (Archivo Catedral Pałencia, doc. núm. 9I nueva clasificación); ni en el de I70I-I7I3 (San Martín Payo, Catálogo del Archivo de la Catedral de Palencia, Publicaciones de la Institución Tello Téllez de Meneses 5 [Diputación Provincial de Palencia, I984], doc. I253, arm. I, leg. IV, doc. 3); solamente el inventario de 1725 recoge una obra que podría hacernos dudar: "[Se anota a la izquierda: existe la Peana] item otra cruz de christal liso de seis dedos de alto con quatro estremos y diez y seis vichas doradas y otras distintas piezas en el pie y valla, y en el asiento del pie 
gaciones arrojen más luz sobre el autor de la pieza, aunque no contiene ninguna marca que identifique al platero. Esto se debe, como explica Maquívar, ${ }^{40}$ a que no era habitual que se firmasen las esculturas, mucho menos las obras realizadas por los plateros, pese a que éstos se consideraban auténticos artistas y a finales del Xvi se distinguían del resto de los gremios y oficios a decir que ellos hacían arte. ${ }^{4 \mathrm{I}}$

El testamento de Juan Fernández Torres del 23 de abril de fundación de la capilla de San Sebastián en la catedral de Pátenci y describe varios objetos con los que la dotó. Entre ellos,

seis piedras negras venidas de la Nueva España guarnecidas a madera y estofadas y doradas con las devociones siguientes: la oración del uerto la prisión [...], azotes a la columna, el ecce omo [sic], Cristo con la cruz a ctastas, Cristo crucificado, las cuales siempre han de estar a los lados del altar de la sacr ía y encargo la conciencia a sus muy reverendos seniores [?] dean e cabildo g porminguna cosa del mundo permitan ni consientan sacarla de allí porque esta ni bolkntad. (f. Iov). Justo después figura una piedra grande de dibersas color benioa de la Nueba España guarnecida de madera con puertas de la una parte y la todo estofado y dorado y [?] el cristal. En una tabla en medio las palara de consagración y en la una puerta escrita la gloria y en la otra el credo tambio de oro y azul y esta piedra así puesta quiero y es mi boluntad que siem es é (f. I ir) en el altar de la dicha sacristía y que para ninguna parte aunque sea are la altar mayor de la dicha iglesia se pueda mudar ni quitar por ninguna nitanera sobre lo qual encárgola en conciencia a los reverendos mis seniores [?] dean e abildo. ${ }^{42}$

quatro escudos con las A mas de San Francisco de Paula también doradas con media naranja. Valla, banquilo, p y ocho garras de plata blanca, que dio el Señor Obispo Pedraza el Jueves santo del ano a setecientos y tres [1703], está quebrada el cañón de christal. Pesa [incompleto]" (Arghiy Catedral Palencia, doc. núm. 95 nueva clasificación, fols. Ior-Iov). Por lo que leemos, a una obra excepcional. No obstante, su medida no corresponde con la de nuestra cruz que tampoco está quebrada ni tiene partes de plata en su color, sino doradas. Tampoco cinc en otros elementos como la heráldica o las garras, a no ser que se añadieran y que luego se hivictan perdido.

40. Maquívar, La escultura religiosa en la Nueva España, 37.

4I. José Arturo Burciaga Campos, Fulgores de un oficio. Plata y plateros en Zacatecas (México: Gobierno del Estado de Zacatecas-Instituto de Desarrollo Artesanal de Zacatecas/Consejo Nacional para la Cultura y las Artes, 2010), 36.

42. Referenciado en San Martín Payo, Catálogo del Archivo de la Catedral de Palencia, doc. I253, arm. VII, leg. I, núm. 20, ff. I-I6. En el primer caso se describen seis piedras negras (¿̨es- 
DOI: http://dx.doi.org/10.22201/iie.18703062e.2014.105.2530

I42 GARCía barRios - PARAda LÓPEZ DE CORSELAS

Las piezas descritas debieron ser objetos raros y apreciados, por ello se indica su procedencia novohispana y se insiste enfáticamente en que no se saquen del lugar que se les ha asignado, ni siquiera para llevarlas al altar mayor de la catedral. Después de describir varios objetos de la capilla, muchos de ellos destinados a su altar o al de su sacristía, el documento recoge "una cruz de cristaren un crucifijo de oro y los rremates de oro". ${ }^{43}$ Lo escueto de la notici oblina plantear una hipótesis con base en el contexto en que se inserta. Es tantrealvendría a sumarse a las citadas sacras, paños de altar, vinajeras, cálices, acetyes, entre otros, con lo cual podría darse por entendido que sería una cru ch ar. Como el documento no tasa los bienes, sino que sólo hace un iny entafo, no se comprobaría si el crucifijo y sus remates eran efectivamente de oropo de plata dorada, y de ahí el posible error, frecuente en estos casos. A liferğncia de las exóticas piedras novohispanas, para la cruz no sería necesarjacer mención de la procedencia, bien porque no se conocía, bien porque su erficialmente dicha obra no resultaría muy distinta a las realizadas en la Pentroula. Lo más significativo para la persona que redactó el inventario se la puesencia de las obras de clara tradición novohispana, las cuales podría hacemos pensar en una misma procedencia para la cruz citada.

La capilla fundada por los Torren fue propiedad del Cabildo catedralicio hasta $174 \mathrm{I},{ }^{44}$ lo cual explica que sus bienes no estén en los inventarios catedralicios conocidos (I667-I725) ci ado en la nota 38. Ello podría aclarar por qué la cruz mexicana que estudiamos no stá presente en los inventarios catedralicios y tal vez se corresponda côla d la capilla de los Torres. ${ }^{45}$ De ser así, la cruz de

pejos de obsidiana?) gy arneciars de marcos de madera y en las que se han estofado y dorado escenas del ciclo d la asión Estarían situadas a ambos lados del altar, no se precisa si en dos grupos con su corespante marco cada uno, o si cada piedra tendría su propio marco y se colocarían tres piedras a un lado del altar y otras tres al otro. En el segundo fragmento se habla de una $m$ resante sacra en forma de tríptico de madera que acogería en su interior una piedra de da itos colores o pintada. Sobre la piedra estarían las palabras de la consagración y en las plortas y el credo.

43 Pay Catálogo del Archivo de la Catedral de Palencia, doc. I253, arm. VII, leg. I, núm. 20, f. I3

44. Payo, Catálogo del Archivo de la Catedral de Palencia, doc. I253, arm. VII, leg. I, núm. 20, ff. IOOV-IOI.

45. Otras opciones posibles las aportan dos documentos distintos. Del siglo XVI, el testamento de Juan de Arce, en el cual realiza donaciones a la capilla de San Gregorio en la catedral en I559: "Crucifijo. + En el altar del vestuario de la sacristía de los dichos capellanes está un crucifijo pequeño de bulto con su calvario depintado [?]". "Cruzes. + En el altar de Sant 
Palencia habría salido muy pronto de México, poco después de su realización; tal vez ello fue precisamente lo que permitió su supervivencia. Por desgracia, la documentación con que contamos no nos permite establecer una hipótesis concluyente por el momento, pero esperamos serán más satisfactorias las nuevas líneas de investigación que se están siguiendo y que se expondrán en futuros trabajos.

\section{La llegada a México de una nueva religio}

Los primeros reconocimientos de la costa yucateca, llevadosa cabo por exploradores como Solís y Hernández de Córdoba desde if I h hasta la llegada de Hernán Cortés en I5I9, supusieron el lento conocimiento de una nueva estructura social y religiosa para las culturas indígena de México. Los castellanos no sólo llegaron con perros de batalla, caba) armas de fuego y trajes de metal, sino también con una nueva rel són que formó parte del control territorial, sustentado en gran medida en/a evangelización de los habitantes de las tierras colonizadas. La Iglesia fue un ns itución fundamental en este proyecto de conquista.

Tres años después de I52I, monento en que Hernán Cortés tomó Tenochtitlan, llegaron los primeros do fanciscanos ${ }^{46}$ como los doce apóstoles de Cristo al Nuevo Mundo. Para facilar a evangelización los frailes repartieron el territorio en cuatro: México Nlaxcala, Huejotzingo y Texcoco. ${ }^{47}$ Más tarde, en I526, llegarían a Méxicolos ayminicos. Estos religiosos, con miras muy diferentes a

Gregorio obisp u cru de cuentas de chrystal con su crucifijo y un pie redondo de madera dorado y en elaltan de santa Ana [?] otra cruz pequeña de madera con su pie redondo de ochavos y dorad ( ayo, Catálogo del Archivo de la Catedral de Palencia, doc. I254, arm. VII, leg. I, núm. 1) Otro documento la recoge entre los bienes tomados a los jesuitas por el cabildo en I769. "Cruz. Item una cruz de christal con un Santo Cristo de plata sobredorada [con] pea our arnecida de los mismo", en Payo, Catálogo del Archivo de la Catedral de Palencia, doc. X, arm. III, leg. I7, núm. II.

40 Nos centramos en los franciscanos pues creemos que la cruz se realizó posiblemente para está orden, por algunos de los elementos que aparecen representados, como la figura de Dios Padre, que parece ser copia de portadas franciscanas españolas. Se ha sugerido que la cruz de altar con calavera de cristal de roca sea una obra franciscana, porque en ella se representa a san Francisco de Asís (Esteras Martín, "Cross Reliquary”, 398).

47. Fray Bernardino de Sahagún, Historia general de las cosas de Nueva España, t. I, Cien de México (México: Consejo Nacional para la Cultura y las Artes, 2000), 37; Constantino 
DOI: http://dx.doi.org/10.22201/iie.18703062e.2014.105.2530

\section{I44 GARCÍA BARRIOS - PARADA LÓPEZ DE CORSELAS}

las de los soldados, funcionarios y gobernadores arribados de España, debían llevar la fe católica a todos los rincones de la tierra conquistada, teniendo en muchos casos que hacerse cargo también de las funciones civiles. Para la evangelización de los nativos, era fundamental conocer las prácticas religiosas que necesitaban erradicar. Así surgieron gran parte de las obras etnohistóricas conocidas ahora. ${ }^{4}$ Con una mentalidad tan alejada de la de los religiosos con in fuerte resistencia a cambiar sus creencias, fue fundamental utilizan mo modelo seguido en España en la evangelización de los moriscos, pues os indígenas, en muchos casos, admitieron la nueva fe, pero consideforowue no era necesario abandonar los cultos anteriores, por no entende que cristianismo exigía exclusividad. ${ }^{49}$ Una de las estrategias de los franciscanos fue separar a los hijos de los principales y educarlos en la nueva religión desdo la infancia. ${ }^{\circ}$ Además aprendieron las lenguas nativas para poder emoelizar, y emplearon un método de enseñanza visual igual que el que se pract caba en la recién conquistada Granada nazarí. También fundaron escucas ater tes y oficios. El iniciador de este gran proyecto fue fray Pedro de Gant r responsable, tres años después de la Conquista, de la primera escuela. ${ }^{\text {II }}$

Las imágenes de arte cristiano fueron cavepara favorecer la difusión del dogma y la moral del cristianismo, sien do éstas las que más influyeron en el arte indígena..$^{2}$ Los misioneros llevaban para sus empresas los utensilios imprescindibles para la liturgia de la mis, como eran cálices, indumentaria religiosa, imágenes de la Virgen con niño, c_cifyos, y aunque la Corona y encomenderos se encargaban de proveer a los religiosos de muchos de estos utensilios, fue necesario elaborar otros muchos para predicar y celebrar la misa, por lo que se acudió a la mano de ob ainágena. América en general y en concreto la región que nos ocupa, Mespanéric), se caracterizaba por contar con excelentes artesanos indígenas, aun ue on unos cánones estilísticos y estéticos muy diferentes de los gustos que se respiraban en el incipiente renacimiento europeo. Partiendo de estam as grabados de origen flamenco y renacentista fueron copiando

Reye Va 10, Arte indocristiano, Colección Obra Diversa (México: Instituto Nacional de Antropologia e Historia, 2000), 8I.

48. Pabló Escalante Gonzalbo, Los códices (México: Consejo Nacional para la Cultura y las Artes, 1998), 26.

49. Batalla Rosado y De Rojas, La religión azteca, I86.

50. Reyes-Valerio, Arte indocristiano, 91.

51. Escalante, Los códices, 29; Maquívar, La escultura religiosa en la Nueva España, IO-I I.

52. Escalante, Los códices, 30. 
imágenes en nuevos materiales, tales como cobre, plata y oro. ${ }^{53}$ Desde el primer momento de la conquista empezaron a llegar plateros. Se fundaron gremios, cuyo santo patrón era san Eligio y sus miembros más eminentes y expertos eran los únicos jueces que legislaban en esta rama del arte y que autorizaban los exámenes para los aspirantes a maestros. En I580 fueron congregados en una sola calle, la famosa calle de los Plateros, para evitar la dispersión de lo trab jos y el fraude. ${ }^{4}$ En principio y para tener el control de la evangelización, a aos os diseños copiados debían ser una réplica fiel del original, pero no se pudo —o no se quiso- evitar que la ideología indígena aportase su partic pra creatividad, 55 y se viese plasmada en algunos detalles que segurament los failes advirtieron, pero consideraron menores o sin relevancia, como parece que de hecho ocurrió en la cruz de altar de la catedral de Palencia cuando su an ífice sustituyó el Gólgota por una montaña cargada de simbolismo pehispanico. Como dice Burciaga Campos, ${ }^{56}$ en la ciudad de México hubg u a gran competencia entre los artesanos en el orden de los plateros espar olesorus ayudantes indígenas. De cualquier manera, la calidad de los objet fue norma de estos magistrales plateros. No obstante, sólo se conserva upa pequeña muestra de su trabajo, pues era frecuente la refundición de la plata paranedarla o emplearla en otras obras. Dicho fenómeno se acentúa si teher en cuenta que parte de la producción se desecharía con el paso del tiempo yor no comprenderse su estética o por considerarse inapropiados sus t mas por parte de la ortodoxia religiosa; incluso objetos tan admirados como los quellegaron a Europa terminaron en muchos casos desechados o abandonâdos almacenes hasta su revalorización de la mano de la etnología. La cruz de Palencia es uno de los pocos supervivientes de su género, e incluso podrane considerarla un unicum por sus características icono-

gráficas.

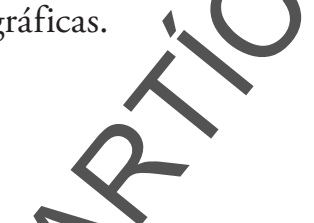

5. Reyes-Valerio, Arte indocristiano, 160-192; Maquívar, La escultura religiosa en la Nueva España, 9 .

54. José Arturo Burciaga Campos, Fulgores de un oficio. Plata y plateros en Zacatecas (México: Consejo Nacional para la Cultura y las Artes/Gobierno del Estado de Zacatecas-Instituto de Desarrollo Artesanal de Zacatecas, 2010), 45-49.

55. Burciaga Campos, Fulgores de un oficio, 45.

56. Burciaga Campos, Fulgores de un oficio, 46. 
DOI: http://dx.doi.org/10.22201/iie.18703062e.2014.105.2530

I46 GARCíA BARRIOS - PARADA LÓPEZ DE CORSELAS

Algunos factores que favorecieron la evangelización

Hay que mencionar que españoles y evangelizadores recién llegados a la Nueva España tuvieron a su favor una religión prehispánica con algunos elementos y símbolos coincidentes con la imaginería cristiana. ${ }^{57}$ Para empezar, los frailes $\mathrm{Ve}$ garon proclamando la nueva venida de Jesucristo, algo que encajó perfectam nte con su concepto de tiempo, pues su historia la dividían en eras o spto ta nueva era de Cristo les fue fácilmente aceptable. Los mexicas explicaron a los castellanos que se encontraban en su quinta era, la cual finalizaría cortanticamente con un gran terremoto, ${ }^{58}$ de modo semejante al Apocalips '. Po otro lado, los pueblos mesoamericanos y en concreto los del centrode Míxico, que eran los que estaban en pleno esplendor político en ese momento,jempleaban árboles

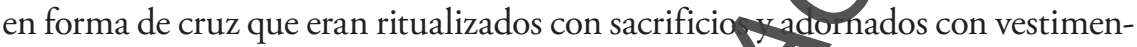
tas y mazorcas de maíz como celebración de las cose has y como signo icónico del propio maíz.59 Todavía hoy día se pueden y r ruates de este tipo en diferentes partes de Mesoamérica. Así, la cruz, em ema del catolicismo, fue asimilada sin demasiada dificultad. Algo muy simila a esteárbol-cruz, fue el primer icono cristiano, la cruz, que vieron los indios do uchán a la llegada de los españoles. ${ }^{60}$

Pero si hay un elemento coincid nt en Mesoamérica de gran relevancia ideológica éste es la montaña sagrada. Concebida siempre como montaña que alberga una cueva; el lugar en a nde todo habita, de donde vienen los dioses y a donde se regresa tras la muerte 'El lugar de comunicación con estos dioses y con sus propios ancestos, gomo veremos. Y es posiblemente esta montaña sagrada la que se recreó en la base de la cruz de altar en sustitución de otra montaña que desde la murerte Jesús tomó un carácter sagrado: el Gólgota.

57. Manu Gutierrez Estévez, "Al margen del Levítico, impurezas amerindias", Revista de Occiden 22 (1999): 69-91.

58 Alf so Caso, El Pueblo del Sol (México: Fondo de Cultura Económica, 200o); Ángel María Oribay, Teogonía e historia de los mexicanos (México: Porrúa, 2005).

59. Lara,City, Temples, Stage, I52-I53.

6o. Lara, City, Temples, Stage, I5I.

6I. Alfredo López Austin, Tamoanchan y Tlalocan (México: Fondo de Cultura Económica, 1994), 9-I8; Alfredo López Austin y Leonardo López Luján, Monte sagrado-Templo mayor (México: Universidad Nacional Autónoma de México-Instituto Nacional de Antropología e Historia, 2011), 39. 


\section{Un Renacimiento plural: el arte novohispano del siglo XVI}

Dentro del debate terminológico del arte novohispano del siglo Xvi existen producciones que destacan por su carácter "mestizo" por la confluencia de elementos indígenas y europeos. Los elementos del acervo indígena se hav querido identificar como "sincretismos" ${ }^{2}$ prehispánicos que definir an un estilo tequitqui ${ }^{63} \mathrm{o}$ bien un arte "indocristiano". ${ }^{64}$ Aunque dichos téryninose contraponen teóricamente, ambos se presentan como simplificaciones que tratan de hacer más comprensible la compleja realidad a la que se refryn lequitqui significa "tributario" en lengua náhuatl, su uso da a entend ér qu el trabajo y estas producciones indígenas se incluían en el pago del tributo los conquistadores españoles. La formulación teórica del término toma com modelo el caso semejante del "mudéjar", teóricamente un arte con pécnicas y motivos decorativos que le serían propios y realizado por musulmanes ometidos en los reinos hispanos cristianos. Dicha formulación teórica, ténino "mudéjar" son tan imprecisos como discutidos hoy día, ${ }^{65}$ como th mbiencreemos que lo es tequitqui. Por

62. Para comprender mejor dicha reali ad el debate que ha generado el término "sincretismo" véase Manuel Gutiérrez Estén - hargen del Levítico, impurezas amerindias”, Revista de Occidente, núm. 222 (I999) 60-91.

63. Definido por Moreno Villa en I94

64. El término "indocristiand uth ado en arte (Reyes-Valerio [1978], Arte indocristiano) ha gozado de gran éxito y difusión, ese a que preferiríamos otros como nepantla. Para apoyar esta afirmación véase Elsa Cecil a Frost, Acerca de nepantla (México: Universidad Nacional Autónoma de México/Academinu Mana de la Lengua, 2008); Ramón Troncoso, "Nepantla, una aproximación al términ.", en ierras prometidas: de la Colonia a la Independencia, coord. Bernat Costany Prado (M arid y bellaterra: Centro para la Edición de los Clásicos Españoles/Universidad Autónonła d Barclona, 201 I), 375-398; Ramón Troncoso, "Crónica del Nepantla: estudio, edición an tación de los fragmentos sobre la Historia general de Anáhuac, de Cristóbal Castillo", tesis loctoral (Universidad Autónoma de Barcelona-Facultad de Filosofía y LetrasDepartane to de Filosofía Española, 20I2), I37-210. El estilo tequitqui fue definido por José Moreno Vha como "mudéjar mexicano" (La escultura colonial mexicana [México: Colegio de Méx 2009 [1942], I0-I9), concretando que “tequitqui, que significa 'tributario', [es] el prodacto nestizo que aparece en América al interpretar los indígenas las imágenes de una religión impartada [...] me dediqué a perseguir los rasgos diferenciales del arte mexicano" (José Moreno Villa, 28 mexicano en las artes plásticas [México: Fondo de Cultura Económica] [ [ ${ }^{\mathrm{a}} \mathrm{ed}$., Colegio de México, 1948], 9). Como puede notarse se trata de una construcción teórica semejante a la del "mudéjar", en línea con la tradicional teoría de los estilos, de tintes formalistas y nacionalistas.

65. Para una actualización sobre la crítica al término "mudéjar" y todo lo que significa véase Juan Carlos Ruiz Souza, "Le 'Style mudéjar' en architecture cent cincuante ans après", Perspective, núm. 2 (2009): 277-286. 
DOI: http://dx.doi.org/10.22201/iie.18703062e.2014.105.2530

I48 GARCía BARRIOS - PARADA LÓPEZ DE CORSELAS

su parte, el término "indocristiano", pese a que nace de una comprensión más completa de las producciones a las que se refiere, adolece de semejante imprecisión, puesto que ¿es indocristiano solamente el arte con elementos "indígenas", hecho por artífices que asumen la nueva religión, dirigidos por monjes cristianos en el siglo xvi? ¿Los artífices han de ser indígenas "sometidos", "tributarios"; y han asumido, o no, o de qué manera, la religión cristiana? ¿Tan poco hay comitentes indígenas? ¿Cómo llamar al arte "prehispánico" hecho end momento de la llegada de los espańoles? ¿El arte "indocristiano" es en todos os casos arte cristiano? ¿Qué elemento indígena define al arte indocristary tequitqui: la técnica, la forma, la estética, la iconografía, la mano d obra la condición "libre" o "sometida" del artífice? ¿En qué proporción tiene que baber elementos occidentales o cristianos y en cuál otra, elementos indínenas ¿Quién o quiénes eran los autores intelectuales de las obras? ¿Cómo dasificar, compartimentar e individualizar un periodo de aculturación, continuilad, pervivencia y cambio tan complejo? Baste con plantear estas interroraples-para poner de manifiesto la debilidad del sistema clasificatorio emplado. No obstante, podemos admitir que sería importante el control ejercido por losplateros que llegan de Espańa y que tienen bajo sus órdenes a orfebres ind ge aus, aunque dicho control atendería más a la gestión de la plata que 10 asuntos representados.

En definitiva, consideramos que quitqui, o el más admisible "indocristiano", no son términos satisfactorio para comprender la riqueza de posibilidades que ofrece el México del siglo vi. Lo que ocurre en dicho momento parece quedar bien expresado nitediante la respuesta que ofrece un indígena al fraile del siglo Xvi Diego Durán cuando éste le recriminaba por realizar prácticas idolátricas: "padre pose cante pues todavía estamos en nepantla, que quiere decir 'estar e medio", ante lo cual fray Diego aclara "que no estaban aún bien arraigadog en t te, que no me espantase; de manera que aún estaban neutros, que ni bien acudían a la una ley, ni a la otra, o por mejor decir, que creían en Dios y ue juntamente acudían a sus costumbres antiguas y ritos del demonio, y esto quiso decir aquél en abominable excusa de que aún permanecían 'en med y yeran neutros". ${ }^{66}$ Este testimonio es muy esclarecedor para entender qux curría en ese momento en el pensamiento indígena. Así, nepantla significa el "fuera de tiempo", el momento que no se rige ni con la lógica, ni por el entendimiento de una o de otra cultura y religión. Es ese periodo justo en

66. Diego Durán, Historia de las Indias de Nueva España e Islas de la Tierra firme, Biblioteca Porrúa de Historia 36, t. I (México: Porrúa, 200I), 237. 
que todavía no se ha difuminado la religión indígena y no se ha arraigado del todo la católica, un momento de coexistencia plena de dos religiones. Estamos en una fase en que ni los frailes lograban entender a los nativos y sus costumbres, ni los indígenas entendían bien quién era ese Dios sacrificado y por qué se le sacrifica a Él en vez de ofrecerle la sangre de los humanos comoalmento, tal y como hacían ellos con sus dioses; muchas veces se veían obli ados a cecir que sí creían en Dios mientras mantenían sus costumbres. Condiquermos que el término nepantla, acuñado además por un indígena mexica nn el iglo Xvi, es más adecuado que los mencionados tequitqui o "indocristing" ara referirnos a la realidad del momento. Así, nepantla afecta no sólo un pensamiento social y religioso, como refleja fray Diego Durán, sino tambien a sus fórmulas de expresión artística. A ellas nos referiremos a partir e ahơra con dicho término.

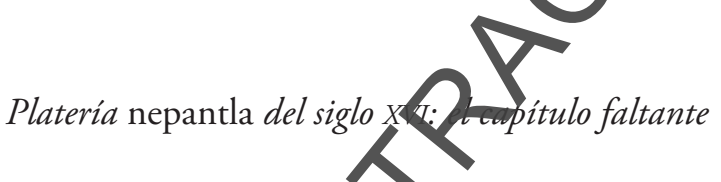

La producción de objetos de plata México continúa con la llegada de los españoles, incorporando diseños euroreoge iconografía cristiana. Entre las piezas más tempranas de la primer plenta novohispana se sitúan la lámpara que Hernán Cortés regaló a la Virgen Guadalupe en $1524,{ }^{67}$ y su envío de alhajas a Carlos V en 1526 inve tan do por Cristóbal de Oñate el 27 de septiembre del mismo año. En el envíose egistran, entre otros muchos objetos prehispánicos y novohispanos ana gruz con un Crucifijo y su base" y un adorno "con un crucifijo de plata con a Virgen al otro lado". ${ }^{68}$ Estos datos atestiguan que en México, al meno hacie 1524-I526 se trabajaba la plata para hacer obras cristianas y, concratantente cruces semejantes a la de Palencia objeto de este estudio. Pese a congcers dicha información, la platería indígena de los primeros años de la Conquisa ha estado ausente en los estudios del llamado arte "indocristiano" al entrario que la arquitectura, la pintura, la escultura y la plumaria, sobre las que existe amplia bibliografía en la que no nos detendremos. Precisamen por ello, Esteras Martín reivindica "un necesario replanteamiento de la cuexionada y negada — hasta ahora — influencia indígena en la platería novo-

67. Esteras Martín, "Presencia de América en España", 392.

68. Anderson, The Art of the Silversmith in Mexico, 52-53; véase P. E. Muller, "The Old World and the Gold of the New", en The Art of Precolumbian Gold. The Jan Mitchell Collection, catálogo de la exposición [Metropolitan Museum of Art, May $9^{\text {th }}$-August II $^{\text {th }} 1985$ ] (Nueva York: Metropolitan Museum of Art), i8. 
DOI: http://dx.doi.org/10.22201/iie.18703062e.2014.105.2530

I 50 GARCÍA BARRIOS - PARADA LÓPEZ DE CORSELAS

hispana del siglo Xvi", que según ella se manifiesta en el "lenguaje decorativo e iconográfico", ${ }^{69}$ en la reutilización de piezas aztecas y el empleo de fórmulas estéticas o técnicas prehispánicas como la plumaria.

Resulta importante mencionar los escasos ejemplares de platería calificables como nepantla, casi todos ellos ya citados arriba, para luego centrarnos e el que consideramos más significativo, la cruz de altar conservada en la c tedral de Palencia (España). Además de ésta, se conoce otra cruz-relicario de phar pereneciente en 1970 a la colección Redo de México, ${ }^{70}$ que tiene una calarera de cristal de roca en su base, de rasgos puramente de tradición prehispán cader centro de México. La cruz de altar de Fregenal de la Sierra (Badajoz, E paña -muy semejante a la de Palencia en tipología y en muchos detalles de la dscoración- y la del convento de San Francisco de Cuzco (Perú) apenas roseen motivos iconográficos prehispánicos, pero su técnica, diseño, marca de lacaliuad mexicana y algunos elementos decorativos permiten situarlas en 5 sto mismo contexto. ${ }^{71}$ Otras piezas de platería mexicana etiquetables bajo e té himo nepantla serían el cáliz del County Museum de Los Ángeles, que nntiene además plumaria y pequeños relieves de madera, todo ello muy vinculado tradiciones locales mexicanas; los mismos materiales se utilizan en un r ta colección privada. ${ }^{72}$ Asimismo, incl Ims nn espejo portado por un mono, tradicionalmente identificado con Huitżopochtli, dios de la guerra, perteneciente al Germanisches Nationalmus cum de Núremberg. ${ }^{73}$ Otras piezas de orfebrería del siglo XVI mexicano, como colgantes devocionales, emplean plumaria, cristal de roca, oro o platarlas, esmalte y pequeños relieves de madera. ${ }^{74}$

69. "Plato virreinal novohispana", 83-84.

70. E A Ceten al Exhibition at the Metropolitan Museum of Art [Sept. 30 ${ }^{\text {th }}$ I970-Jan. $3^{\text {rd }}$ I97I] (Nueva York: Metropolitan Museum of Art, 1970), pieza 306.

7I. Véase Esteras Martín, "Platería virreinal novohispana”.

72. "Platería virreinal novohispana"; "Cruz de altar", cat. III-3, I96.

73. Kennedy Easby y Scott, Before Cortés, pieza 305.

74. Existen en varios museos, citamos los ejemplares del Musée du Louvre (Inv. OA 598, OA 2316 y OA 6I80), el British Museum (Inv. WB.I83) y el Walters Art Museum de Baltimore (Inv. 6I.120). 


\section{Iconografía de la cruz de altar de Palencia}

Hasta ahora, como se ha comentado, los únicos estudios sobre la cruz de altar de la catedral de Palencia y su soporte los había realizado Esteras Martín, quien en varios artículos fue la primera en advertir que el Gólgota era un monte argado de animales, proponiendo inicialmente que estaban relacionados "in dy da $\$ 5$ "probablemente" 76 con un bestiario medieval. En otro trabajo quediza más adelante, identifica que "se representa un complejo y hermétioe programa iconográfico explicado con signos y símbolos de la tradición in ty y añade que "con esta fórmula conceptual el mensaje se hacía más asim able para ambos grupos (frailes e indios)". ${ }^{77}$ Sus aportaciones se especifican los estudios publicados en los años 2006 y 2007,,$^{78}$ al decir que reprod ice la montańa o tierra, con los cuatro elementos simbolizados por los animates prantas, entre otros, "cuyos significados concretos parecen aludir a un progr ma iconográfico de carácter cristológico, referido al dogma de la muert varesurrección de Cristo, y también a la redención de la humanidad". 79 unque acertadamente Esteras Martín advierte en sus últimos artículos que o es un bestiario medieval sino que identifica elementos de un monte de trat ció mesoamericana, nos alejamos de la idea de que forme parte exclusiv me un programa iconográfico de carácter cristológico referido a la muerta resurrección y redención de la humanidad. Creemos que además esta non aña juega el papel de monte sagrado, lugar de origen de seres sagrados, humaros y vida.

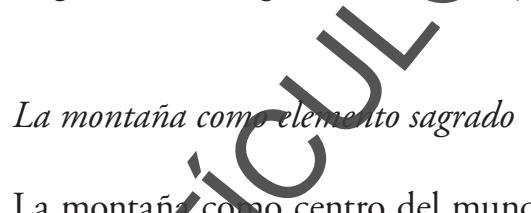

La montań cono centro del mundo es un concepto compartido por la gran mayoría de culturas antiguas. En el Mediterráneo, la idea de la montaña como centro - veces sustituida por una columna o un árbol— ${ }^{80}$ es de procedencia indeeurorea. Entre los egipcios la montaña ejerce de sostén de los cielos, algo

7) Esteras Martín, "Platería virreinal novohispana”, Izo.

76. Esteras Martín, "Plata labrada mexicana en España”, 5I.

77. Esteras Martín, "La platería hispanoamericana”, I24.

78. Esteras Martín, "Altar Cross", I97; "Cruz de altar", 201.

79. Esteras Martín, "Cruz de altar", 20 I.

8o. Véase Sotirios Mayassis, Architecture, religion, symbolism. Origines, formation et évolution de l'architecture, vols. I y II (Atenas: BAOA, I964). 
DOI: http://dx.doi.org/10.22201/iie.18703062e.2014.105.2530

I 52 GARCía barRios - PARAda López DE CORSELAS

curioso viendo la escasez de montañas que tienen en su geografía real. En cambio, para los semitas, no es el sostén de los cielos sino que su función se aproxima más a la de enlace comunicante entre cielo y tierra. Esta montaña es el lugar de vida y en su cúspide se alza el árbol de la vida que, como se advierte en algunos sellos asirios de Mitani, crece desde un cuerpo de agua en lugar de la montaña misma, hecho que enfatiza la conexión existente entre el simbo ismo de agua y vida. ${ }^{81}$ La cruz de Cristo según las Actas de Pedro del siglo promestra como victoriosa y al igual que Cristo no permanece en la tierra sino gle también asciende al cielo, como se deja ver en el ábside de San Approren Classe en Rávena, donde reviste un significado marcadamente es foló ico-triunfalista, y personificará a la Iglesia desde la Edad Media. ${ }^{82}$

El Monte Gólgota donde se crucificó a Jesús en ép ca rômana fue un lugar donde se ajusticiaba a los condenados a muerte. Los angeristas Mateo, Marcos y Juan coinciden en nombrar Gólgota al monte dende se crucificó a Jesús, mientras que Lucas es el único que lo menciona con o a arrio. ${ }^{83} \mathrm{El}$ significado es el mismo, ya que la voz "Gólgota" en arameo snificu cráneo o calavera, que derivará en Calvario (de calva). La toponimil puede derivar de que el Gólgota era, como todavía se ve, un monte pelado, se a, pedregoso, árido, sin vegetación de ninguna clase o, como explican alguno martires como san Jerónimo y los evangelistas, su nombre puede deberse a la muchas calaveras que allí se amontonaban, entre las que suele destac rse de Adán.

\section{La montaña mesoamericana}

La montaña enłM soan érica también posee unas características semejantes, lo que lleva a pensa que el concepto de montańa como lugar de origen y vida, núcleo de conexún con el cielo y la tierra, era un pensamiento generalizado entre las alt mas antiguas. Es muy posible que esa imagen de monte calavera que represen al Gólgota fuese un concepto fácilmente asimilable por los indígena da Mesoamérica. Así, como se ha comentado anteriormente, en algunas piezas readizadas en los primeros momentos de la Conquista, maravillosas cala-

81. Othmar Keel, La iconografía del Antiguo Oriente y el Antiguo Testamento, Bibliotecas de Ciencias Bíblicas y Orientales 9 (Madrid: Trotta, 2007), 25.

82. Lara, City, Temples, Stage, I58.

83. Eloíno Nácar Fuster y Alberto Colunga Cueto, Sagrada Biblia, Biblioteca de Autores Cristianos (Madrid: Editorial Católica, I980), I IOI, II25, II63, II9I. 
veras, claramente mexicanas, toman vida como Monte Gólgota. Esto fue posible precisamente por la relación tan estrecha que los mexicas tenían con la muerte. ${ }^{84}$

En Mesoamérica, desde la primera gran cultura, la olmeca (I500-400 a.C.), se deja traslucir la importancia que la montańa y la cueva de su interior tienen como lugar de origen de dioses y ancestros, así como lugar de culto y riturar existiesen o no estos montes en su paisaje geográfico real. Esta montaña sagrada la que en esta cruz se equipara y sustituye al Gólgota. El cerro en generath Mesoamérica se entiende como una montaña en cuyo interior se encuenty una cueva que refiere al lugar de origen, ese lugar mitológico de donoferedían las culturas del centro de México (figs. 6a-c). La concepción d una ueva matriz como origen de los dioses y los hombres fue compartida desde tiempas remotos por todas las culturas mesoamericanas. Como apunta Andred J. St 9 ne, ${ }^{85}$ los olmecas estaban asentados en regiones planas, nunca cerca demontañas-cuevas, por lo que la ideología de la montańa-cueva como espacio r ual o sagrado debió tener su origen en un área donde las cuevas tuvier no natuerte presencia en el medio ambiente, probablemente en las cadenas nonta La ciudad de Teotihuacan habría sidg su conereción más afamada. La pirámide del Sol se edificó como la montaña qu cuobría la cueva sobre la que se asentaba, reproduciendo el lugar de origen co hocído como Chicomoztoc "la cueva de los siete nichos", el legendario lugar da partida de muchos de los pueblos habitantes del centro de México con la $\mathrm{qu}$ se encontraron los españoles y cuyos antepasados habrían emigrado del nerte del país. ${ }^{86}$ Desde al menos el Preclásico Medio (I 200-400 a.C.), se advrute en la iconografía que la montańa alberga una cueva en la que residen los anc stros y seres sobrenaturales. Estas montañas-cuevas se representaron desde de igen como seres animados y criaturas de rostros zoomorfos con una gran boca abierta en forma de cuadrilóbulo. Iconográficamente, estas repentaciones combinan el rostro del cerro andromorfo con una gran

\section{2 specia}

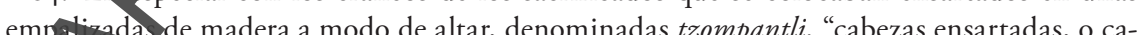
bzas 1 hilera" (véase Michael Graulich, "Los lugares, las piedras y los altares de sacrificio",

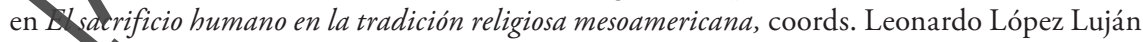
y Guilhêm Olivier (México: Instituto Nacional de Antropología e Historia/Universidad Nacional Autónoma de México, 2010), 410.

85. Andrea J. Stone, Images from the Underworld. Naj Tunich and the Tradition of Maya Cave Painting (Austin: University of Texas Press, 1995), 20, fig. 2.6.

86. Véase López Austin y López Luján, Monte sagrado; Marie-Areti Hers, "Chicomóztoc. Un mito revisado", Arqueología Mexicana, núm. 56 (2002): 49. 
DOI: http://dx.doi.org/10.22201/iie.18703062e.2014.105.2530

I 54 GARCÍA BARRIOS - PARADA LÓPEZ DE CORSELAS

boca abierta con el signo "piedra", un indicador semántico que refuerza la idea de que el cerro se realizó de piedra y tierra, como se ve en el Monumento 9 de Chalcatzingo (véase fig. 6a). Esa gran boca es la extensión de la tierra, señalada por plantas que brotan de las cuatro esquinas del mundo. ${ }^{87}$ Éste es el icono estándar empleado en todos los sistemas iconográficos de Mesoaméricapara representar la montańa-cueva; una gran cabeza antropomorfa de b ca a ier ta que se podía mostrar de perfil, en planta, o en sección, y tuvo tama fuerza e importancia ideológica que dio lugar al jeroglífico que emplean lo aztecas para designar ciudad, altépetl (fig. 6b).

La montańa sagrada en forma de boca antropomorfa, se r presentaba de perfil, solía reproducir en la parte exterior la vida del mante, animales y vegetación, como se aprecia en las pinturas mayas de Sa Bantolo (ca. Ioo a.C.Ioo d.C), ${ }^{88}$ cuya primera escena se desarrolla dentro te-uncerro que toma forma de rostro antropomorfo de perfil. En él se advierte n ay claramente la nariz, el ojo, el hocico, el colmillo en forma de estalac ito fauces abiertas, espacio que forma la oquedad de la cueva en cuyo in eriorestá el dios del maíz. La base o suelo de la cueva es el cuerpo emplumado de ura serpiente (fig. 6c). En el exterior de este monte se observa prácticamon le misma fauna y flora que eligiera el platero indígena dieciséis siglos nas arde para reproducir el monte que sujetaría la cruz de altar. Se dejan ver tres ves componiendo un nido colgante; una serpiente enroscada en un árb or a vorando a un pajarito; otra serpiente en la parte baja del cerro; un lagarto son ando al interior de las fauces; un jaguar que acaba de devorar a un animisl, tal vez a una ave, indicado por la sangre que sale de su boca y por la garra qu avanza hacía las aves que tiene enfrente. Además, hay árboles, vegetación nu variada y flores, elementos que Karl A. Taube asocia a la montaña fl (ida) un concepto generalizado y antiguo, no sólo compartido por los gry pos nayas, sino también por los grupos del centro de México y los del suroeste ntreamericano. ${ }^{89}$ En el pensamiento prehispánico era un lugar

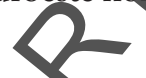

87. Frant Reilly III, "Cosmología, soberanismo y espacio ritual en la Mesoamérica del Frma to", en Los olmecas en Mesoamérica, ed. John. E. Clark (México: El Equilibrista, 1994), 230-259.

88. Willram Saturno, Karl A. Taube et al., "La identificación de las figuras del muro oeste de Pinturas Sub-I, San Bartolo, Petén”, en XVIII Simposio de Investigaciones Arqueológicas en Guatemala, eds. Juan Pedro Laporte, Bárbara Arroyo et al. (Guatemala: Ministerio de Cultura y Deportes/Instituto de Antropología e Historia Asociación Tikaly/Foundation for the Advancement of Mesoamerican Studies, 2005), 647-655.

89. Karl A. Taube, "Maws of Heavens and Hell: The Symbolism of the Centipede and Ser- 

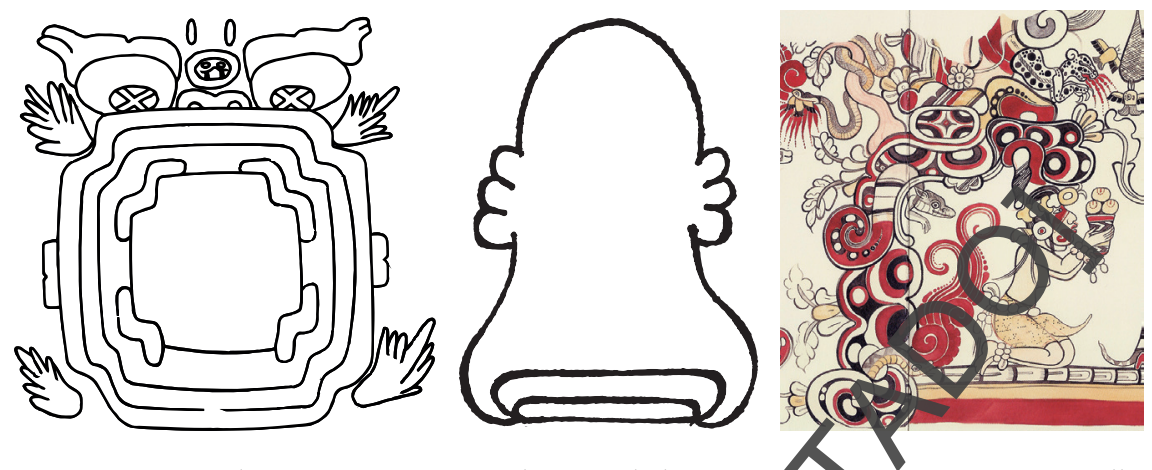

6. Montaña sagrada mesoamericana: a) olmeca, Chalcatzingo. Monmento 9 (según Reilly, "Cosmología, soberanismo y espacio ritual", vid supra n. 87 25 I, fig. I 5. I 8); b) los mexicas empleaban como jeroglífico de ciudad el icono de cerro-cueva otlt petl (Códice Mendoza, dibujo tomado de Frances Berdan y Patricia Rieff Anawalt, Coofce Andoza [Berkeley: University of California Press, I99I] Io); c) también en la cultura na a montańa-cueva era lugar primordial y de origen de los dioses y ancestros, tomado de arno y Taube et al., "Los murales de San Bartolo" (vid infra n. 98).

ancestral, paradisiaco, que ofrec a aceso sobrenatural desde el inframundo acuoso a los cielos. El autor mantr ne que entre los grupos mayas de Chiapas se cree en la existencia de la tiqnamontańa en flor, que funciona como axis mundi primordial, al ser esta mon aña a que sostiene el antiguo árbol del maíz ancestral, el lugar de vida al que López Austin ${ }^{90}$ identifica como Tamoanchan.$^{9 \mathrm{I}}$

Por otro lado, no se quede olvidar la trascendencia que supone en el centro de México el citado ane epto de Chicomoztoc, "la cueva de los siete nichos". La imagen de este lúgar mítico de origen se encuentra en la Historia ToltecaChichimeca 22 an acumento que describe los orígenes y la historia del pueblo de Cuauhtinchan, como un cerro representado en alzado y en planta (fig. 7); preci-

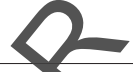

pen Classic Maya Religion", en Antropología de la eternidad: la muerte en la cultura maya, ets. A drés Ciudad Ruiz, Mario Humberto Ruz Sosa et al. (Madrid: SEem, 2003), 405-442; "Flove Mountain: Concepts of Life, Beauty and Paradise among the Classic Maya", Res: Anthropology and Aesthetics, núm. 45 (2004): 69-98.

90. López Austin, Tamoanchan y Tlalocan, 9.

91. Véase también Lara, City, Temples, Stage, 152.

92. Véase la edición de Paul Kirchhoff, Lina Odena et al. (México: Instituto Nacional para Antropología e Historia-Centro de Investigaciones Superiores/Secretaría de Educación Pública, 1976). 


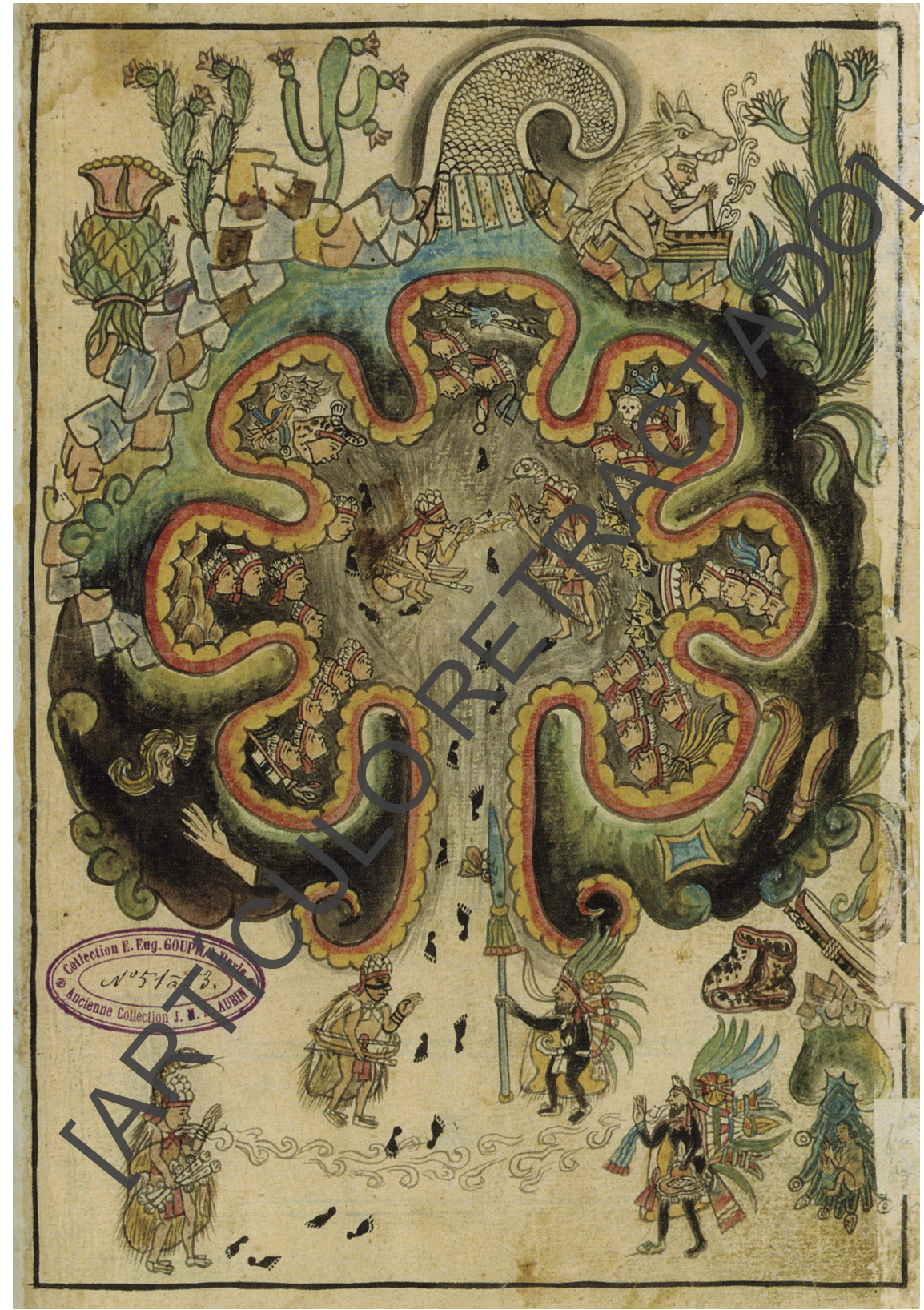

7. Chicomoztoc, representado en la Historia Tolteca-Chichimeca, f. I6r. Montaña con las cuevas en su interior de donde salieron los grupos que poblaron el centro de México. Imagen tomada de http://amoxcalli.org.mx/laminas.php?id=046\&ord_lamina=046_I6r\&act=con 
samente este manuscrito lo encargó hacia I544 el noble nahua Alonso de Castañeda como demostración del prestigio, rancio abolengo y propiedades de dicho pueblo en su disputa de lindes con Tepeaca. ${ }^{93}$ Pocos años después, en el mismo contexto los linajes locales promovieron el claustro del convento de Cuauhtinchan (ca. I560), conjunto que tiene grandes superficies de color roijzo una fuente decorada con águila y cabezas de jaguar, animales que se reprieron pintados al estilo indígena flanqueando una Anunciación en también se introdujeron elementos sagrados prehispánicos — comel bulto de reliquias forrado con piel de jaguar y alusivo a Quetzalcóatl- retranados con sus prestigiosos orígenes. ${ }^{94}$ Con todo ello se recrea el lugar frigitario con el que se identificaba la comunidad indígena que promovió el-conjunto, lugar denominado en el manuscrito de De Castañeda precisam nte Quauhtli ichan, ocelotl ichan y Tlatlauhqui tepexioztoc, "el sitio del águla, el sitio del jaguar, la cueva roja"95 o bien Tépetl Cotoncan "el cerro, ellug r de la muesca o partidura", Cuauhtli ichan, océlotl ichan ("lugar del ág iil, lugar del jaguar"), Tzouac xilopetl ("el lugar del lazo, el cerro del jilote", paraterminar la descripción anotando "Tlalauhqui tepexioztoc inteyoca inmachiyocan", ("el rojo lugar de la cueva del peńasco es el lugar de su honra ce conocimiento"). ${ }^{96}$ Nuevamente nos encontramos ante la relación menta ha-cueva cargada de simbolismo relacionado con el origen de un grupo.

Volviendo a la represen ación del Chicomoztoc del manuscrito, en alzado se recrea la geografía del nonte, con plantas identificativas de tierras áridas, como son los cactus, roos y un personaje haciendo fuego cubierto con una piel de lobo, que representa mundo salvaje e incivilizado. En la planta se representan los siete pichos cuevas con los fundadores de los linajes que llegarán al centro de Mc ico tonde se culturizarán y formarán poderosos reinos. Aquí se configurzel ancepto de cueva-cerro y se destaca la relevancia de este concepto como lugan de origen.

93. Pas Escalante Gonzalbo, "El patrocinio del arte indocristiano en el siglo Xvi. La inicr try las autoridades indígenas en Tlaxcala y Cuauhtinchan”, en XX Coloquio Internusion l de Historia del Arte. Patrocinio, colección y circulación de las artes, ed. Gustavo Curiel (Mex co; Universidad Nacional Autónoma de México-Instituto de Investigaciones Estéticas, 1997), $215-235$.

94. Escalante Gonzalbo, "El patrocinio del arte indocristiano", 226-235; Los códices, 252-257.

95. Escalante Gonzalbo, "El patrocinio del arte indocristiano", 230.

96. Pablo Escalante Gonzalbo, "Iconografía y pintura mural en los conventos mexicanos. La aportación indígena", en Felipe II y el arte de su tiempo (Madrid: Universidad Autónoma Metropolitana), 235-257. 
DOI: http://dx.doi.org/10.22201/iie.18703062e.2014.105.2530

I 58 GARCía BARRIOS - PARAdA LÓPEZ DE CORSELAS

Muchos de estos cerros están relacionados con ritos de fertilidad y se entienden como morada de los dioses de la lluvia a los que se les hacían sacrificios humanos. Todavía hoy día, la mayoría de los grupos indígenas hacen rituales de fertilidad a los seres sagrados de la lluvia en sus montańas y tierras de cultivo. ${ }^{97}$ Es interesante observar que muchas veces estas montañas están cuxtodiadas por animales salvajes. En la región de Tierras Altas de Guate mala lo mayas tzutujiles piensan que los jaguares y serpientes son los gyandranes de estos lugares sagrados..$^{98}$ Asimismo, referencias del centro de Maxico sitúan a Tláloc, dios de la lluvia y la abundancia, como el dueño de provensa área ubicada en el interior de la tierra denominada Tlalocan. ${ }^{90}$ Segun López Austin es el lugar de la muerte, porque es donde viajan los muertospor el ataque de rayos, o por algún motivo que esté en consonancia co el atua, como los ahogados. ${ }^{100}$ Es una montaña hueca llena de frutos pore en ella hay eterna estación productiva. Diferentes cronistas mencionapal lalocan como el lugar de la abundancia, tierra de riquezas o "paraíso teren "Asimismo, Batalla Rosado y De Rojas explican que dentro de los araisos, al Tlalocan se le describe como un lugar de gozo, donde nunca falta almento, todo es verde, el maíz, los bledos, el chile, los frijoles, las cala zas entre otros. ${ }^{\text {Ior }}$ Para López Austin, el Tlalocan está en relación co 1 circulación de lo invisible, de los cursos que siguen las sustancias sutiles as cuales dan naturaleza, que transforman y animan a los seres del mu do; son sitios de origen y destino de estas sustancias sutiles a las que podemos llamar sustancias anímicas, almas o fuerzas divinas localizadas en al interior de las criaturas. ${ }^{102}$ Esto es claro en las fuentes que hablan de la agnstitución de los hombres. Según las concepcio-

97. López Austili y ópez Luján, Monte sagrado-Templo mayor, I5-I8.

98. William Sa urn Karl A. Taube et al., "Los murales de San Bartolo, El Petén, Guatemala. Parte I. El mural del norte", Ancient America 7 (2005): I3-I6.

99. En el Jio p de los Coloquios, Sahagún comenta que Tláloc es el que da a la gente el valor y el mando vios son los que dan las honras, cauallerisa, dignidades y reinos". Por tanto, como coment anté "Tlallocan en los diálogos de I524: la respuesta de los sabios nahuas", man crit presentado en Actas del II Congreso Europeo de Lationamericanistas América Latina: ruce de Culturas y Sociedades. La Dimensión Histórica y la Globalización Futura [Halle (Alemana) del 4 al 8 de septiembre de i988] 4-5, Tlalocan también es el lugar en donde se trasmite el poder y Tláloc es el gobernante de ese espacio mítico interior; quien preside el principio y el fin de los reinos.

Ioo. López Austin, Tamoanchan y Tlalocan, 9.

Ior. Batalla Rosado y De Rojas, La religión azteca, 82 .

I02. López Austin, Tamoanchan y Tlalocan, I7-I8. 
nes mesoamericanas el ser humano está formado por varias entidades anímicas y el Tlalocan se relaciona con su gestación o con su destino final. Lo anterior no sólo se refiere al hombre, las almas de los otros seres mundanos también van a estos lugares míticos y de ellos provienen. Aunando todos estos datos podremos teorizar sobre las intenciones posibles del artista a la hora de ubicar a Cristo crucificado en una montaña sagrada de tradición me oamgricana.

\section{La montaña de la cruz de altar}

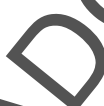

La cruz de altar se asienta sobre una base cuadrangular rodsada de una moldura de arcos conopiales con querubines en su interio y renata en las esquinas en cuatro caballos ${ }^{\mathrm{IO} 3}$ alados que hacen de soporte. Atser ra base cuadrada hace que el monte tome forma piramidal, insinuándoserri as en las esquinas de los cuatro lados. La falda delantera del monte retra queatracia atrás más que las demás. El crucifijo queda ubicado en el vértice perıor de la montaña.

El monte está cargado de animałes vertebrados e invertebrados, insectos, anfibios y aves, además de plantas (fist a-c). Todos se distribuyen en torno a pequeños huecos cilíndricos qeiolel orfebre. Si se tiene en cuenta la cantidad de animales salvajes que ap recen representados, estos huecos podrían servir para sujetar plantas fleres, como si se tratase de una montaña florida, algo imprescindible seg un explica Taube en la iconografía prehispánica de cerros y montańas. ${ }^{104}$ ta manera de adornar la montaña de vegetación y fauna se mantuvo al menos hasta el siglo XVIII en las representaciones que de ésta se hacía en fiestan rivules durante el periodo virreinal. Cuentan los cronistas que para la fiestallarada "del volcán" que los gobernantes indígenas realizaban en la capital gratenalteca, congregaban a cientos de indios lujosamente ataviados a la usanz prehispánica, provistos de antiguos instrumentos musicales y armas en torno a la representación de un volcán salpicado de grutas y adornado con thares, arbustos, árboles pequeños, loros, guacamayas, monos, venados, Io Los caballos de esquina se representan con la boca abierta y la lengua de fuera, forma
estética no empleada en la iconografía europea, sin embargo, en la del centro de México el
venado, animal con el que asimilaron al caballo, siempre se representa con la boca abierta y
la lengua de fuera, incluso en los jeroglíficos, por lo que el orfebre estaba componiendo su
concepto particular de caballo, muy probablemente sin haber tenido uno real como modelo
(comunicación personal Alfonso Lacadena García Gallo, 20I3). 104. Taube, "Flower Mountain", 69-98. 

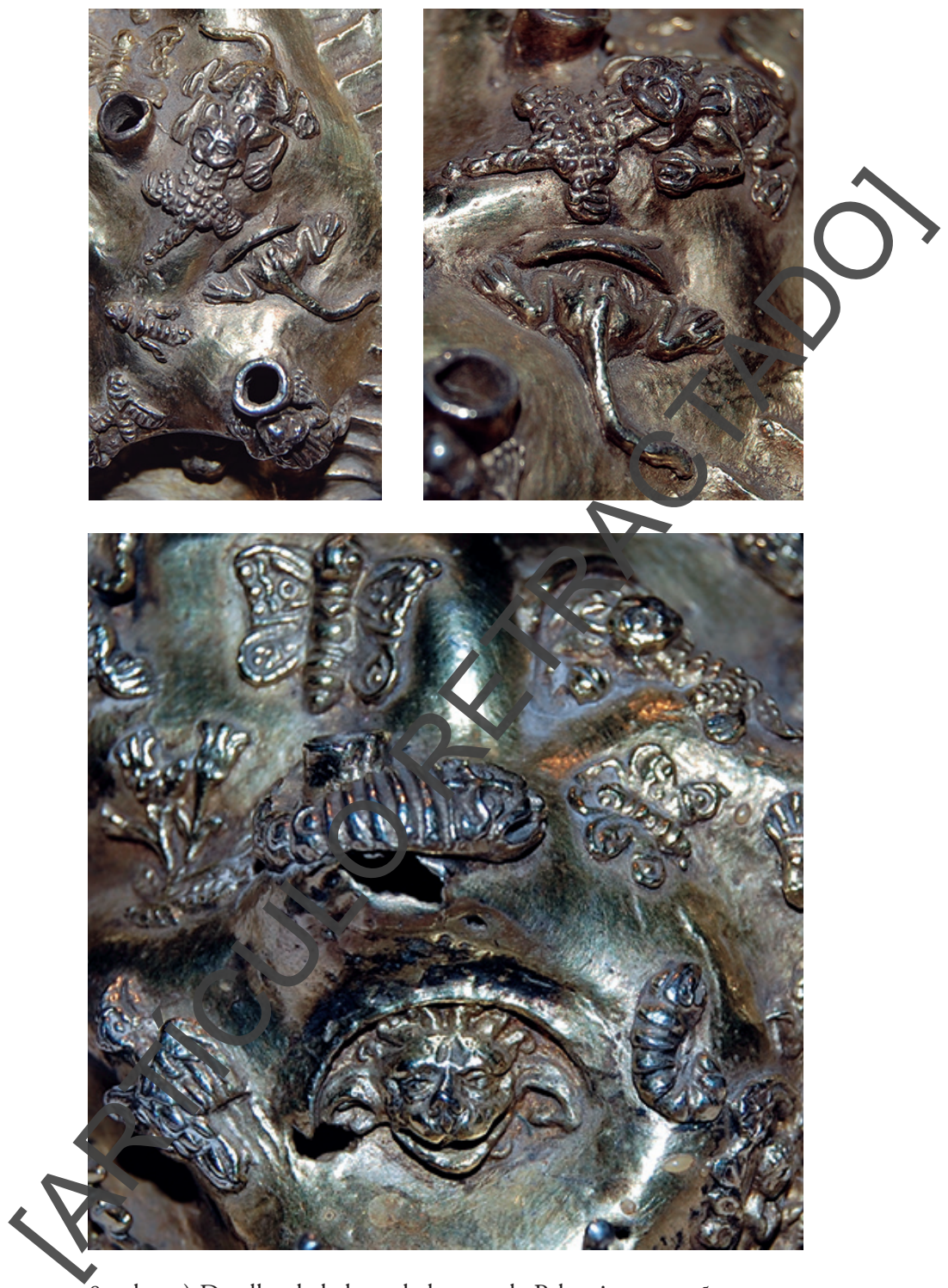

8 a, b y c) Detalles de la base de la cruz de Palencia, montańa mesoamericana reconocible por la gran cantidad de fauna y vegetación que en ella se solía representar por ser un lugar de origen y de vida. Se advierten jaguares, lagartos, tortugas, serpientes emplumadas. En esta figura destacamos varios de los felinos representados, posiblemente pumas u ocelotes, algunos de ellos devorando reptiles. 
jabalíes, pizotes y tapires que los indios salían a cazar para el festejo. ${ }^{\text {105 }}$ Podría ser a estos elementos de madera a los que aludía Antigüedad del Castillo-Olivares en su descripción de la cruz recogida más arriba. ${ }^{106}$ Por otro lado, en la parte baja de la falda delantera de la montańa se advierten dos pequeños promontorios equidistantes entre sí y a la misma altura, con tres ranuras ignâs cada uno, tal vez se trataba de los puntos de anclaje que sujetaban do figu as En caso de que esto fuese así, es probable que fueran la Virgen y smour, los dos personajes que suelen acompañar a Jesús en el Calvario. A est hay que añadir un elemento que incluye el orfebre. Se trata de un camino sryoso y escalonado, a modo de escalera, que arranca en la base del mo fe y ega hasta la cruz de Jesús. Dicha escalera recuerda, en el ámbito prehicpániọ, a las grandes avenidas que se dirigen a los templos ubicados en la pa te superior de las montañas o a las propias escaleras que ascienden hasta los momos prehispánicos, aunque también es posible que fuese la escalera que serep senta inclinada en la cruz en los ciclos pasionarios. La escalera formó pa te de iconografía cristiana de los primeros momentos en las cruces atriales ondese sintetizaba la pasión de Cristo, con las insignias de ésta representada en sus earas. Más acertado resulta pensar que a finales del siglo xv se difundie ho por Europa estampas plenas de indulgencias, con el tema de las armas de Cristo, dispuestas heráldicamente en forma de panoplias; las mismas que se representaron posteriormente en varios conventos agustinos y dominicos a Nueva España. ${ }^{107}$ La semejanza con la disposición de la escalera en la nont ña mesoamericana podría entenderse también como un elemento de tindición cristiana.

La iconografía que presenta el monte sigue el mismo patrón mencionado con anterioridadempledo desde el periodo Preclásico para reproducir la montaña mesoarner cana Los animales están en plena actividad, algunos despla-

105. Francisa Antonio de Fuentes y Guzmán, Recordación florida. Discurso historial, natural, $m$ rey al, militar y politico del Reyno de Guatemala, ed. C. Sáenz de Santa María, Biblioteca d Autores Españoles 230, 25 I, 259, vol. I (Madrid: Atlas, I969 [I960]), 346-350 y Ma Humberto Ruz Sosa, "Danzas para resguardar memorias", en El ritual en el mundo naya. L lo privado a lo público, eds. Andrés Ciudad Ruiz, María Josefa Iglesias Ponce de León et an (Andalucía/América: Sociedad Española de Estudios Mayas-Grupo de InvestigaciónPatrimonio Cultural y Relaciones Artísticas/Centro Peninsular en Humanidades/Ciencias Sociales la Universidad Nacional Autónoma de México, 2010), 313-340.

I06. Antigüedad del Castillo-Olivares, "Orfebrería religiosa en Palencia", 37.

107. Elena Isabel Estrada de Gerlero, Muros, sargas y papeles. Imagen de lo sagrado y lo profano en el arte novohispano del siglo XVI (México: Universidad Nacional Autónoma de MéxicoInstituto de Investigaciones Estéticas, 20I I), I83-I87, fig. II. 
DOI: http://dx.doi.org/10.22201/iie.18703062e.2014.105.2530

zándose, cazando y comiendo. En otras ocasiones entran y salen de cuevas. La fauna es típicamente americana, muy similar a la representada en la montańa de la ciudad maya de San Bartolo explicada arriba y que se encuadra en la larga tradición mesoamericana. Abundan los reptiles: lagartos, camaleones, tortugas y lagartijas. De forma especial destacan las representaciones en las aristar de las laderas, frontal y trasera del monte de dos serpientes de cascabel cor las cabe zas y cuerpos adornados por plumas. Así el orfebre inserta dentro tue contexto aparentemente sacro a una de las entidades más importantes le Mesoamérica: la serpiente emplumada. También se diseñaron batracios princtpalmente sapos y ranas. No faltan los insectos, como larvas, saltamon (es, a ejas y avispas, moscas; destaca de forma especial la mariposa por el simbolisno tan importante que tiene desde la cultura teotihuacana. En el progr ma thmbién se incluyeron felinos, en especial jaguares y pumas, que desde dentro de cavernas devoran a otros seres. Igualmente, en este cerro también hab an aves, algunas parecen rapaces, otras acuáticas, y en otros casos recurdacolibríes libando flores. ${ }^{108}$

La fauna aquí representada es similar en lgunos casos a la de los manuscritos prehispánicos, como se puede ver en la lagarija de la lámina i8 del Códice Azoyú I, ${ }^{\text {109 }}$ realizado entre I42 I y I454 C lochinola, actual estado de Guerrero. Esta similitud hace pensar que of 1 febre tuviese en su poder algunos libros en el momento en que se realizó la cru de altar, pues en el centro de México, al contrario de lo que ocurrió en tra zonas de Nueva España, se respetó la escritura náhuatl y los documento ese titos. Por eso nos inclinamos a pensar que tomaron algunos elemento de gstos códices, así como de otros diseños incluidos en la decoración y ornanentación de portadas y fachadas de conventos realizados en piedra, como leles o pájaros, y posiblemente, pese a desconocer su edad, de todo la que conservaba en su memoria el orfebre, que en otro tiempo fueron imágen habituales de ídolos en los programas escultóricos y arquitectónicos. Como expone fray Toribio de Benavente

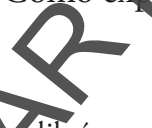

ıo El Elibrí se consideraba desde época prehispánica un animal mágico, relacionado con los lioses, a veces aparecía como mensajero de éstos. No en vano, en los catecismos en náhuatl que realizaron los frailes para evangelizar, es el Espíritu Santo el que toma forma de colibrí (véase Miguel León-Portilla, "Catecismo náhuatl en imágenes", Arqueología Mexicana. La Colección de Códices de la Biblioteca Nacional de Antropología e Historia (edición especial), núm. 42 [20I2]: 7I-72), aunque aquí no tenemos justificación para pensar que ésa fue la intención del orfebre al incluir a estas aves.

I09. Elizabeth Jiménez García, "Códice Azoyú I", Arqueología Mexicana, núm. 42 (2012): 37. 
los indígenas también tenían ídolos de figuras de culebras [...] hay unas víboras grandes que en la cola hacen unas vueltas con las cuales hacen ruido, y a esta causa los españoles las llaman víboras de cascabel [...] tenían también ídolos de aves, así como de águilas, y tigre [...] y de los lagartos de agua, hasta sapos y ranas [...] de otras muchas cosas tenían figuras e ídolos de bulto y de pincel, hasta de las mariposas y pulgas y langostas, y grandes y bien labradas. Acabados de destru esto ídølos, dieron tras los que estaban encerrados en los pies de las cruces lodos los destruyeron. ${ }^{\text {IIO }}$

Además de esta fauna, hay corrientes de agua que sigue dise os prehispánicos, serpientes emplumadas que podrían estar emulando un de los dioses más importantes de Mesoamérica, y en las aristas trase as se encuentran tres niños encerrados en hornacinas vegetales.

Todo esto convierte a esta pieza con tal progr na iconográfico en algo único dentro de las representaciones american seerta etapa del primer contacto. Así parece que el orfebre siguió los dis nos pehispánicos expuestos más arriba, en los que se incluían los diferent niveles que forman su ecosistema; el del interior de la tierra mediante larvas _us? nos; ${ }^{\text {II I }}$ el lacustre, con sapos y ranas; el terrestre, con mamíferos y rep ile. vél aéreo, con las aves e insectos voladores. Son muchos los componentes que conforman el exterior de la montaña, por eso para este trabajo se har elegido sólo algunos de los elementos que más han llamado nuestra atención es a composición por el contenido simbólico que poseen. El primero a do taca de forma especial es el icono atl, que en náhuatl significa "agua", el cual coscribe una corriente de agua en forma de río o manantial. El segundo erá aderpiente emplumada, de vital importancia para el pensamiento religio oo in lígena. El tercer apartado está dedicado a las plantas, por su diseño pehispanico. El cuarto se centra en la mariposa. Y el quinto analiza a los niños de tro de hornacinas vegetales que verdaderamente ha sorprendido hallar nste contexto sagrado.

I Io. Fray Toribio de Benavente, Historia de los Indios de la Nueva España, ed. Edmundo O’Gorman, Sepan Cuántos I29 (México: Porrúa, I990), 27.

II I. Se parece a la representación del ocuilli, "gusano", cuerpo con segmentos como se ve en el Códice Mendoza (véase Cuaderno de signos náhuatl de Alfonso Lacadena García-Gallo). 
DOI: http://dx.doi.org/10.22201/iie.18703062e.2014.105.2530

I64 GARCÍA BARRIOS - PARADA LÓPEZ DE CORSELAS
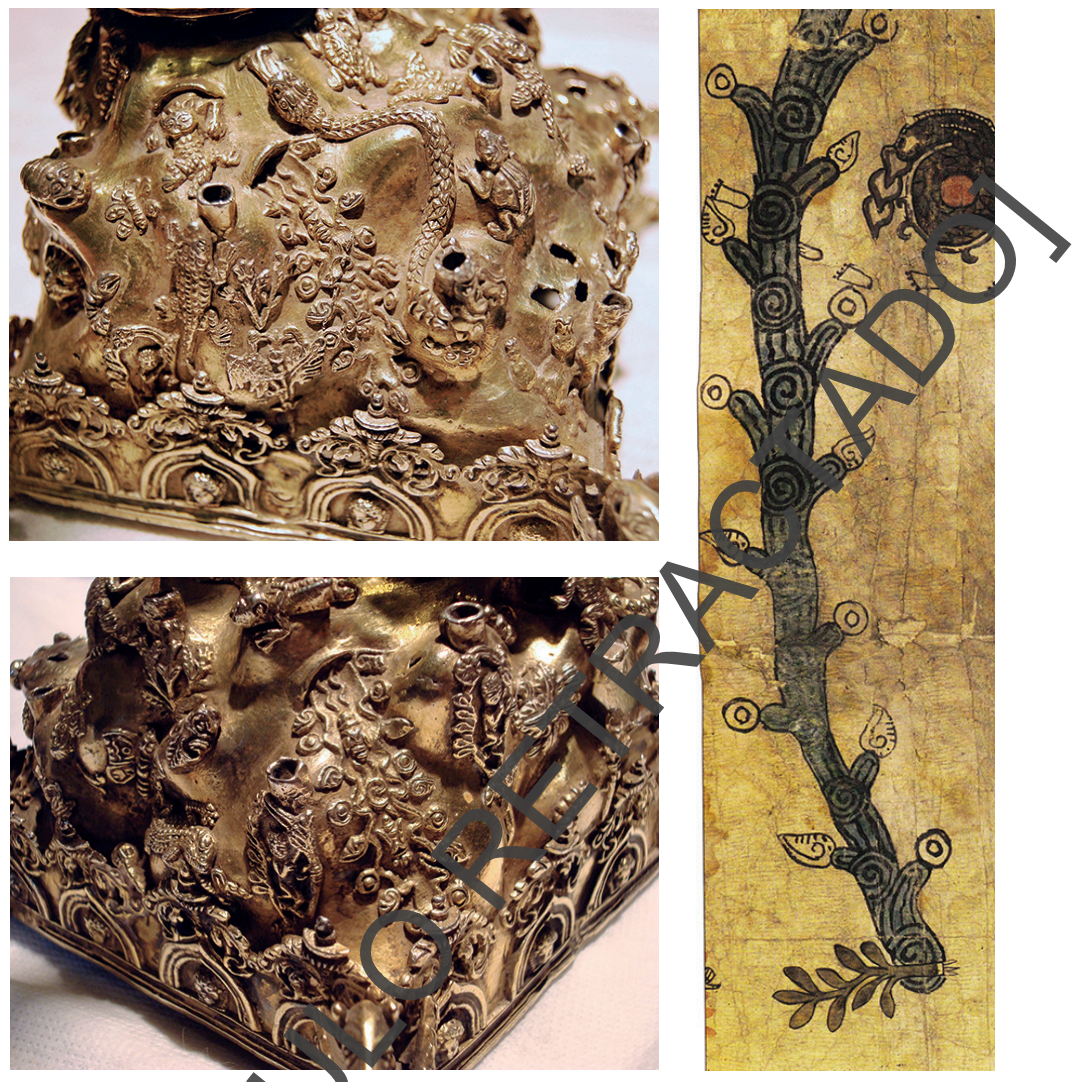

9 a y b) Signo nábert an "gua”, empleado en iconografía como corriente de agua, manantial orrío (vistas de la base de la cruz de Palencia); c) signo atl, tomado de Carmen Aguilen Codice Huamantla”, Arqueología Mexicana, núm. 42 (2012): 5 I.

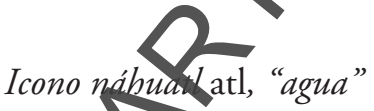

Icono nábuar atl, "agua"

En el lado izquierdo de la montańa se proyectó una corriente de agua, que como sugirió Esteras representaba el icono azteca de agua (figs. 9a-c). ${ }^{\text {II2 }}$ En realidad es un río cuyo curso recorre el monte de lado a lado en diagonal, despareciendo en el interior de la montaña bajo la cruz de Cristo y volviendo a manar de

I I2. Esteras Martín, "Cruz de altar”, 20 I. 


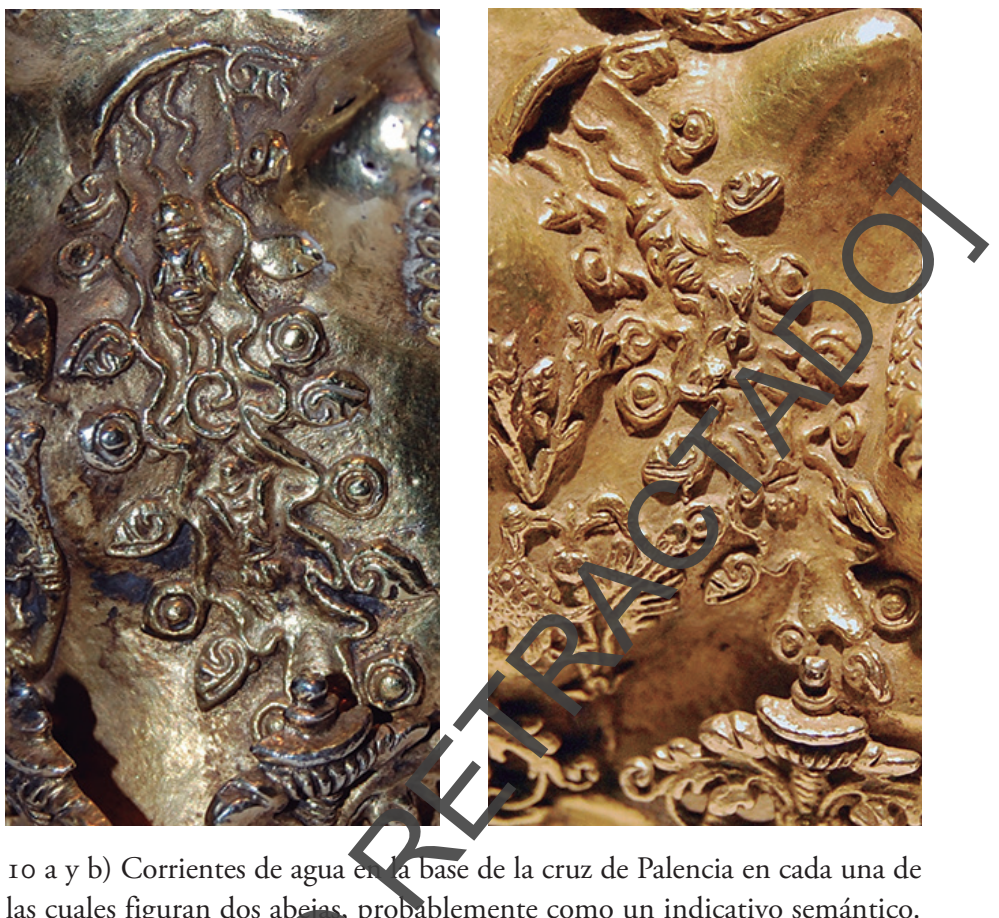

las cuales figuran dos abeias probablemente como un indicativo semántico.

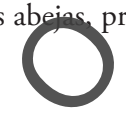

nuevo por la falda trasera. Siempre los cerros mesoamericanos están acompañados de ríos o aguasuterráneas, espacios my relevantes en su concepción de vida y fertilidad (De forma especial destacamos este signo atl, "agua”, lo que nos hace pensar qua realizaron la pieza en un momento muy temprano del contacto. El icono atto atl es un signo que gráficamente representa corrientes de agua adorna en sus ramales con caracolas y chalchihuites o cuentas de jade, dos elemento que están en relación con el campo semántico de la lluvia y el agua en geperal. En cada una de estas corrientes de agua el artista incluyó dos moscas acustres (figs. Ioa y b), probablemente para reforzar el campo semántico de corriente de agua, como se hacía en algunos manuscritos prehispánicos. ${ }^{113}$ También es posible que al incluir a las moscas lacustres pretendiese darle un valor

I 13. Alfonso Lacadena García-Gallo, Cuaderno de introducción a la escritura jeroglifica náhuatl, Apéndice I de la lista de signos (Madrid: s.e., 20I2.) 
DOI: http://dx.doi.org/10.22201/iie.18703062e.2014.105.2530

I66 GARCÍA BARRIOS - PARADA LÓPEZ DE CORSELAS

semántico más concreto, identificándolo con una única corriente de agua o río que recorre el monte por el exterior, ocultándose al pasar bajo la cruz y brotando de nuevo por la ladera posterior. De esta manera, se señala que existía una corriente subterránea, como se ve en el Tlalocan teotihuacano y en otras montañas concebidas como paraísos. Johanna Broda comenta que "según la cosmovisión mexica, los cerros contenían las aguas subterráneas que llenaba el e pa cio debajo de la tierra, este espacio era el Tlalocan, el paraíso del diodravia, y de él salían las fuentes para formar los ríos, los lagos y el mar”.

\section{La serpiente emplumada}

La serpiente que se representa en la montaña de cruz de altar de Palencia (figs. I Ia y b) es en forma y diseño muy similar po no decir igual, a las serpientes talladas en los monumentos aztecas do 10 arios previos a la Conquista (como por ejemplo la importante coleccion conservada en el Museo Nacional de Antropología de México, o aquelyás que llegaron como regalos al Viejo Mundo). Se trata de la serpiente emplumn a ge era representada como una serpiente de cascabel con plumas de qu tz len a cabeza y en el cuerpo. La serpiente emplumada es una figura de origen ancestral en Mesoamérica, reconociéndose en iconografía desde las repres enta iones olmecas, aunque es durante el poder político de Teotihuacan, ciudalub cada a $50 \mathrm{~km}$ de la actual ciudad de México, entre los siglos III y vu de nuestra era, cuando esa figura tiene un papel preponderante que se iría difundiendo por todo el territorio mesoamericano, y de forma especial por elcreama debido a las relaciones existentes en ese momento entre ambas ul uras. Durante el periodo de esplendor de Teotihuacan fue símbolo de guẹra ,estuvo relacionada con el origen de los linajes. ${ }^{115}$ También II4. Joh Ra bröda, "Ritos mexicas en los cerros de la cuenca: los sacrificios de niños", en La mana el paisaje ritual, eds. Johanna Broda, Stanislaw Ivaniszewski et al. (México: I Tacional de Antropología e Historia/Consejo Nacional para la Cultura y las Artes/ Instituto Nacional Indigenista/Universidad Nacional Autónoma de México, 2007), 296-297.

II 5. Saburo Sugiyama, "Rulership, Warfare, and Human Sacrifice at the Ciudadela: an Iconographic Study of Feathered Serpent Representations", en Art, Ideology, and the City of Teotibuacan, ed. Janet Catherine Berlo (Washington: Dumbarton Oaks, 1992), 205-230; "Teotihuacan as an Origin for Postclassic Feathered Serpent", en Mesoamerica's Classic Heritage: From Teotihuacan to the Aztecs, eds. David Carrasco, Lindsay Jones et al. (Boulder: University Press of Colorado, 2000). 


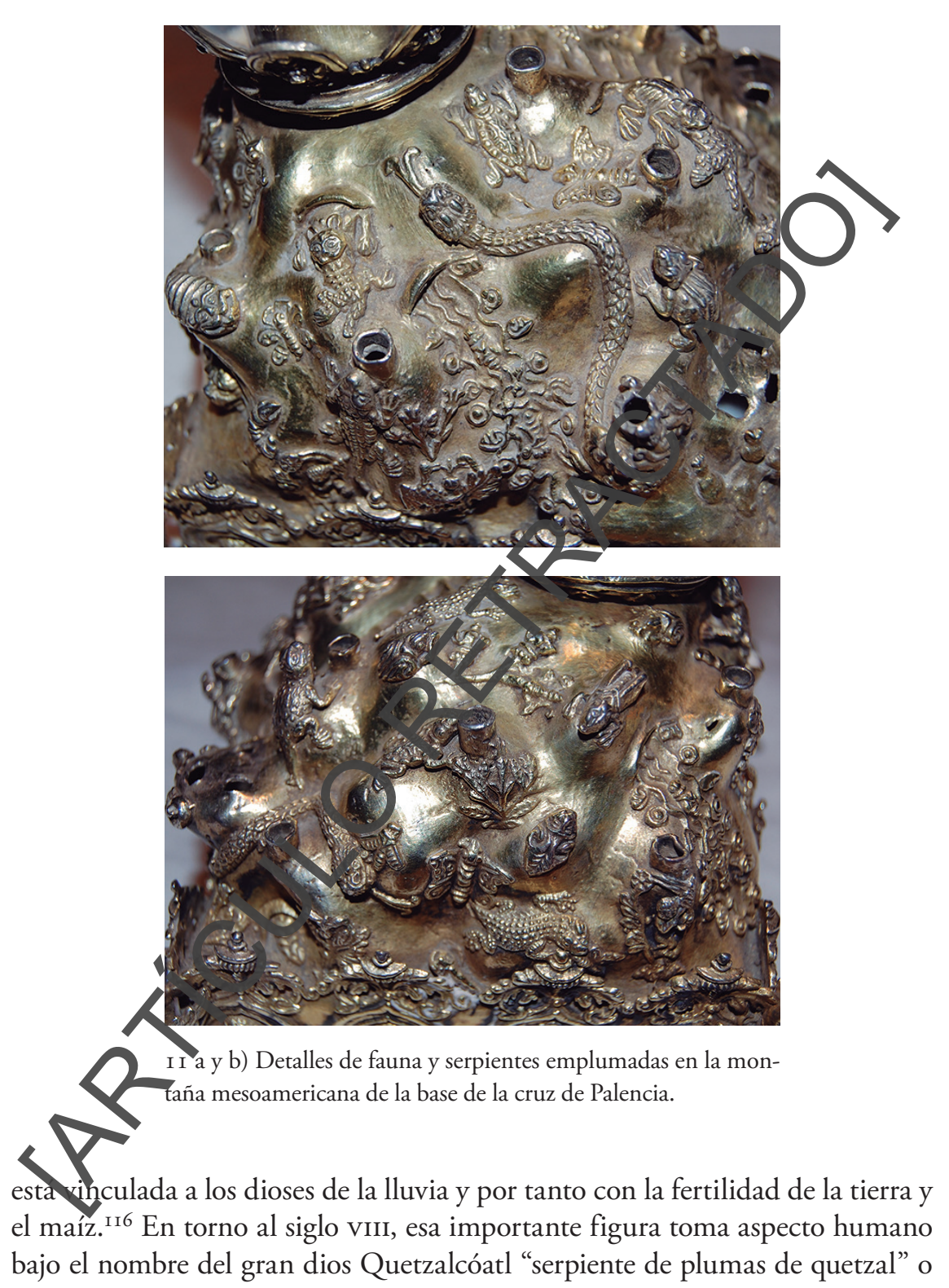

I16. Enrique Florescano, Quetzalcóatl y los mitos fundadores de Mesoamérica, Colección Pasado y Presente (México: Taurus, 2009), 71; 106. 
DOI: http://dx.doi.org/10.22201/iie.18703062e.2014.105.2530

I68 GARCÍA BARRIOS - PARADA LÓPEZ DE CORSELAS

"serpiente emplumada". ${ }^{17}$ Ésta será una de las figuras que tomarán los aztecas a su llegada al centro de México (siglo XIII d.C.) de la antigua ciudad de Teotihuacan que, aunque había perdido su poder y había colapsado unos 500 años antes, todavía era lugar de culto y peregrinación de otros grupos culturales del centro, y de hecho fue el sitio de donde los aztecas tomaron sus dioses y aiseños arquitectónicos.

Según Pablo Escalante Gonzalbo en el arte del siglo xvi mexieanonsten evidencias de la asimilación de Quetzalcóatl con Cristo en tres hivele de significado: como "traducción" del precioso sacrificio de sangre, cono revalorización" de los antiguos rituales indígenas, como las prácti as do autosacrificio por parte de los sacerdotes o el sacrificio de los guerreros y como "afirmación histórica" de la existencia en Mesoamérica de fenóme os sçmejantes a los descritos en los Evangelios o bien de que se tenía noticinde los mismos. ${ }^{I 18} \mathrm{La}$ cruz de Palencia podría estar abierta a estas lecturas-qu zá realzando el paralelismo de Cristo con Quetzalcóatl, así como el crá đee legitimador de esta divinidad para los indígenas.

Flora

Las flores, árboles y plantas en genera son elementos indispensables en la configuración de la montaña sagrad a m soamericana, precisamente porque simbolizan la vida natural del monte, in cual el hombre no es capaz de subsistir. La flora que se advierte en las rovresentaciones de montañas del centro de México es muy similar a la que elige en rrebre del siglo Xvi para contextualizar el monte de la cruz, ubicándonoen durismo entorno geográfico. Algunas son plantas cactáceas, de la región lel ce htro de México. Además, si como se ha propuesto anteriormente, es p sib que los huecos fuesen para ubicar y sujetar plantas y flores, de esta manera el nonte estaría lleno de vegetación que ahora no vemos. Entre las plantas re regentadas se advierten al menos tres diseños diferentes de fuerte tradición prehroánica (figs. I 2a-e). Estas flores y plantas, que pueden tomar diversas form?, se encuentran esculpidas en una gran variedad de obras religiosas; en

I17. Florescano, Quetzalcóatly los mitos fundadores.

I18. Pablo Escalante Gonzalbo, "Cristo, su sangre y los indios. Exploraciones iconográficas sobre el arte mexicano del siglo xvi", en Herencias indigenas, tradiciones europeas y la mirada europea [Actas del Coloquio de la Asociación Carl Justi y del Instituto Cervantes de Bremen. Bremen, 6-9 de abril, 200o], ed. Helga von Kügelgen (Fráncfort del Meno/Madrid: Vervuert/ Iberoamericana, 2002), 75-79. 

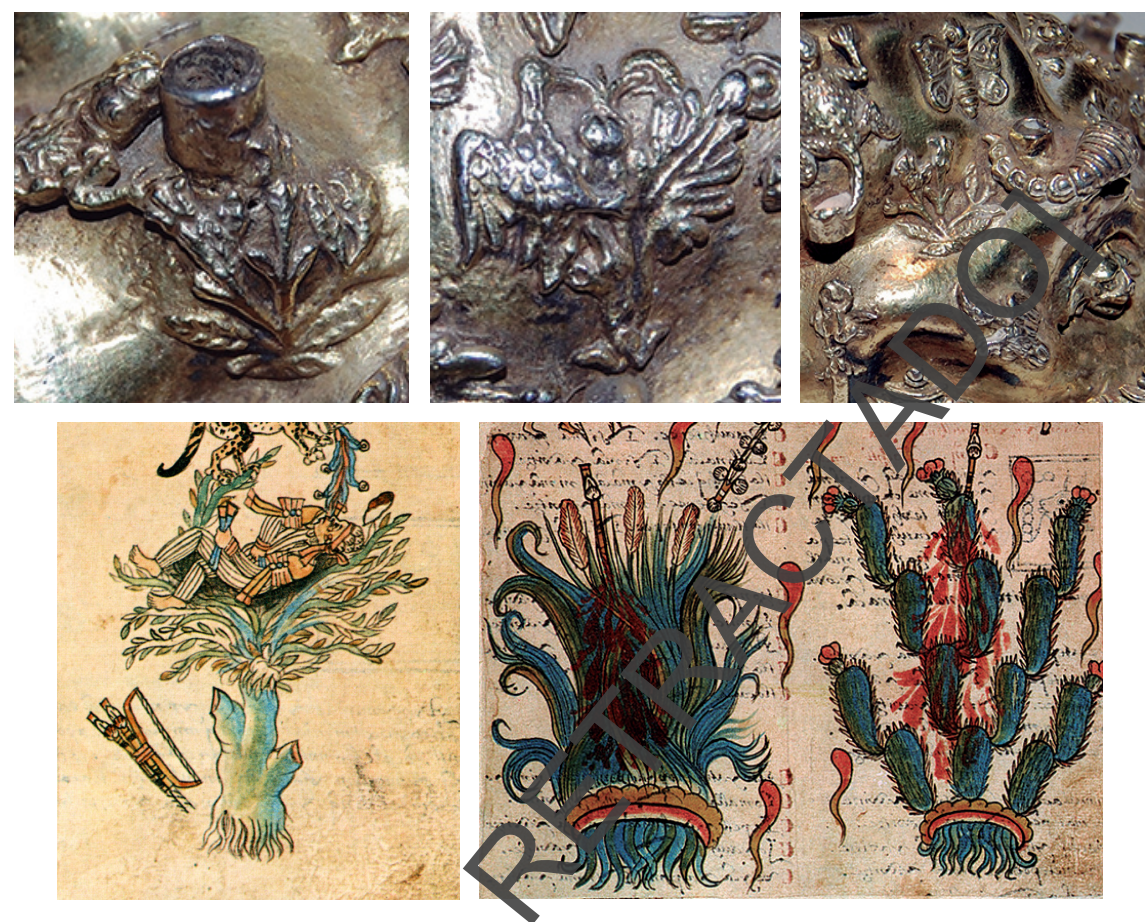

I 2 a, b y c) Detalles de las plan as representadas en el monte de la cruz de Palencia. Siguen la tradición prehispánica de diseñan s con raíces; d y e) representaciones de plantas, tomadas de la Historia Tolteca-Chichimeca, ff. $20 \mathrm{y}$ y $23 \mathrm{r}$, http://amoxcalli.org.mx/laminas.php?id=04680rd_ lamina $=046 \_20 r \& a c t=0 n$ ttp://amoxcalli.org. $\mathrm{mx} /$ laminas.php? id=046\&ord_ lamina $=046 \_23$ r\&act=con

pilas de agua bencita, en jambas, en frisos y en celdas de capillas, en portadas de templos, enstrumentos, como teponaztli (tambor realizado con un tronco hueco), en ares, entre otros. ${ }^{\text {II }}$

En ladera trasera de la cruz de altar se encuentra la única flor que se reprse frontalmente, y su tamaño es desproporcionado respecto a las otras pantas. Recuerda en su forma al glifo del quinto sol azteca, o de 4 movimiento, 4 llin, formado por cuatro círculos en esquinas y uno central, que representaba el quinto sol, la era en la que se encontraban los aztecas a la llegada de los españoles y que sería destruida por un terremoto. Otra variante de este signo

I19. Constantino Reyes-Valerio, Arte indocristiano, 303-316. 
DOI: http://dx.doi.org/10.22201/iie.18703062e.2014.105.2530

I7O GARCÍA BARRIOS - PARADA LÓPEZ DE CORSELAS
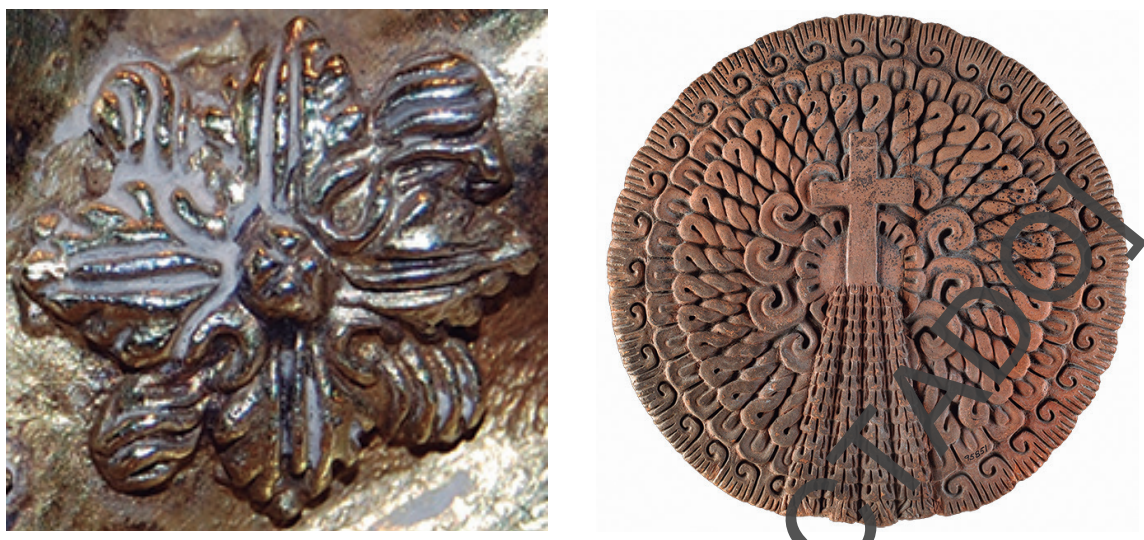

I 3 a) Metáfora de la herida sacrificial: detalle de la gran flor to base de la cruz de Palencia; b) el disco de cerámica de San Juan Teotihuacan conservadonen e field Museum of Natural History, Chicago.

era una flor de cuatro pétalos con el âculocentral, similar a esto. ${ }^{\text {I20 }}$ También podría parecerse a las que se encuentun ađornando el frontón de la portada de la iglesia franciscana de Santa María de Tulpetlac, en el Estado de México, ${ }^{\text {I2I }}$ que han podido evolucionar te las flores prehispánicas esculpidas en altares mexicas, como el de Tepetlacalli, tonde se reproduce un árbol florido que toma forma cruciforme sobre et cur asienta un águila. ${ }^{\mathrm{I} 22}$ En cualquier caso, observamos su gran tamañó desproporción respecto a las otras plantas y flores del monte. Ante una m radamas atenta, notamos que entre los cuatro grandes pétalos dispuestos en cus sitúan a su vez cuatro chalchihuites de los cuales brotan chorros de san se. Cabe conjeturar que se trata de un icono de sacrificio, como sucede en yn discorde cerámica mexicano del siglo XVI, procedente de San Juan Teotihuac.on en él cual la flor se acompaña de una cruz, "una flor abierta, metáfora de aberda sacrificial en los cantos indígenas" (fig. I3b), ${ }^{123} \mathrm{o}$ bien en una cruz lel ario del convento de Malinalco, en cuya cruceta se representa una flor

I20. Reyes-Valerio, Arte indocristiano, 310 ; 316, foto IoI.

I21. Reyes-Valerio, Arte indocristiano, 288, fig. I3.

I22. Reyes-Valerio, Arte indocristiano, 31 I; 316, foto I04.

I23. Escalante,"Cristo, su sangre y los indios", 77. 


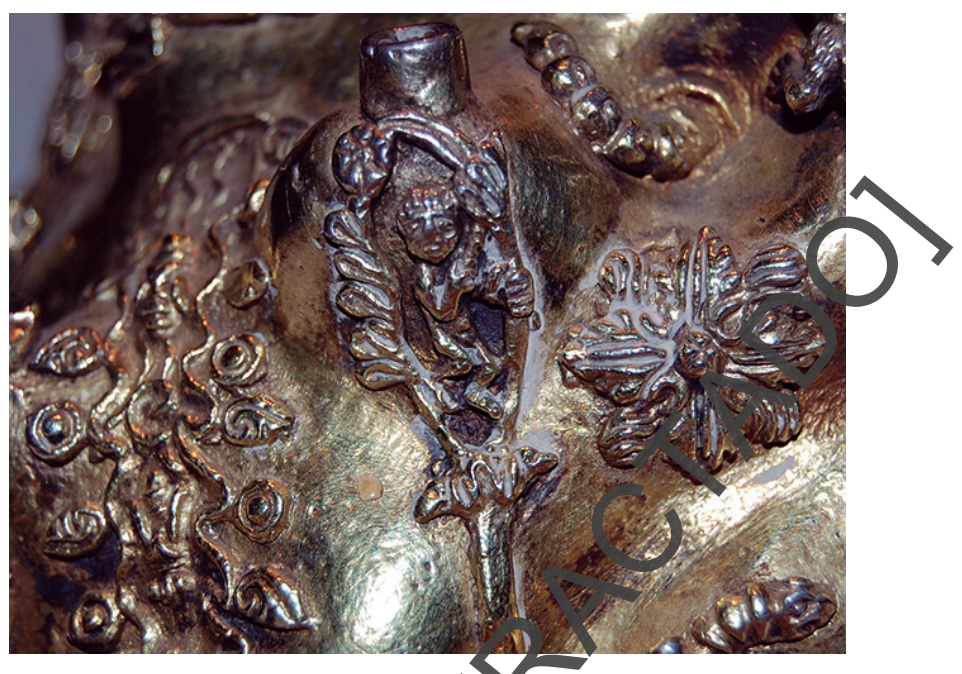

I4. Detalle de la base de la cruz de P/encian el que se aprecia el glifo del agua, un niño en hornacina vegetal $\mathbf{~ l a ~ g r a n ~ f l o r ~ a b i e r t a . ~}$

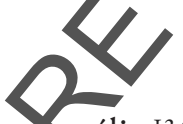

de la cual mana sangre que cae a uncáliz. ${ }^{124}$ La gran flor de la cruz de Palencia se sitúa junto a uno de los non tal vez connotando su sacrificio, en paralelo al de Cristo (figs. I3a y I4).

Por otro lado, en est montaña de la cruz de Palencia las plantas se reproducen con raíz, un dise o de tradición puramente prehispánica que conserva el orfebre. Tanto en Mehuscritos como en monumentos en piedra se identifican plantas con raíz como se puede ver en Ixmiquilpan. ${ }^{\mathrm{I} 25}$ No descartamos tampoco gre arunas plantas y flores representadas aquí aludan a algún lugar concreto, el alal nunca seremos capaces de descubrir, pues si hay algo que no posee sta montaña son topónimos escritos en náhuatl, lo cual no quiere decir querel arifice no incluyese ciertos elementos iconográficos. De este modo, se $\checkmark$

I 4 Sobre este tipo de representaciones y sus precedentes prehispánicos, en las que la flor se relaciona con la sangre y el sacrificio, véase James B. Kiracofe, "Cultural Integration and Architectural Fusion as a Strategy for Survival: The Iconographic Use of Disk Freeze in Pre-Columbian and Early Colonial Buildings" (paper presented at the Cultural Transmission and Transformation in the Ibero-American World, I200-I80o Conference) (Virginia: Polytechnic Institute and State University, I995), en http://interamericaninstitute.org/vpi_I995_conference.htm I25. Reyes-Valerio, Arte indocristiano, 288, fig. I5. 
DOI: http://dx.doi.org/10.22201/iie.18703062e.2014.105.2530

I72 GARCÍA BARRIOS - PARADA LÓPEZ DE CORSELAS

puede afirmar, sin riesgo a equivocarse, que la vegetación y flora plasmadas en esta montaña por el orfebre seguían los patrones, todavía no olvidados, de la figuración prehispánica, pues la traza y diseño son muy similares a los de los manuscritos y monumentos en piedra realizados por los aztecas antes de la llegada de los españoles. En trabajos posteriores identificaremos los posibles thos de plantas aquí reproducidas.

\section{Mariposas}

En las concepciones mesoamericanas la mariposa es un con características mágicas por su capacidad de transformación y ur o de los más representados desde antiguo en su iconografía, como se advie en esta cruz (véanse figs. 9 y ro). Según Seler la mariposa tiene un papel reler nte en la mitología de los mexicanos, así se advierte desde las pinturas muresede Teotihuacan hasta bien entrada la etapa virreinal. ${ }^{126} \mathrm{El}$ autor man ane que la mariposa representa el fuego y está en relación con el anciano dos del Yuego, por lo cual también está vinculada a escenas donde entra en jue el agua y el fuego. Al ser un insecto relacionado con los ancianos se ascia también con la muerte y los ancestros. Aunque según Seler, no alude a culquier muerto, sino únicamente a aquellos que residen en lo más profana de la tierra, más allá de la gran agua. ${ }^{127} \mathrm{La}$ mariposa es en realidad una reprentación de los héroes y de los jefes muertos, porque tanto en el lengraje gomo en la representación era una expresión de guerra y un fetiche que carg ban los guerreros en la espalda y en las rodelas, tal y como describe frar-Bendino de Sahagún, "usaban otra rodela, hecha con plumas ricas, y el centro della era oro, redondo, labrada en ella una mariposa [...] También ys senores llevaban a cuestas una manera de divisas que se llama itzpapalot"; " la mariposa de obsidiana, que según Seler es el demonio de Tamoanc an lugar del nacimiento, el oeste mítico, el lugar de origen de todas las culturas à Mesoamérica. ${ }^{129}$ Sahagún también coincide en que "es esta divisa hechade manera de figura del diablo, hecha de plumas ricas. Y tenía las alas y la con a manera de mariposa, y los ojos y uñas y pies y cejas y todo lo demás

I26. Eduard Seler, Las imágenes de los animales en los manuscritos mexicanos y mayas, trad. Joachin von Mentz, ed. Brigida von Mentz (México: Casa Juan Pablos, 2004), 299-300.

I27. Seler, Las imágenes de los animales, 299-300.

I28. Seler, Las imágenes de los animales, 748.

I29. Seler, Las imágenes de los animales, 300. 
DOI: http://dx.doi.org/10.22201/iie.18703062e.2014.105.2530

eran de oro. Y en la cabeza désta poníanle dos manojos de quetzal", ${ }^{130}$ el ave más prestigiosa de Mesoamérica por sus plumas. De manera similar, el fraile describe otro tipo de mariposa, la xochiquetzalpapalotli, "mariposa de flor de quetzal", también realizada con plumas y oro considerada igualmente como el diablo por estar elaborada con materiales preciosos que debían brillar de forma des (umbrante con el sol. En la página 43 del Códice Mendoza se ve a los guerr ros que portan en la espalda un emblema de mariposa, así como guerreros canostajes están adornados con una mariposa. ${ }^{\mathrm{I} I}$ Este emblema de mariposa ne ra e a una especie de amuleto que se decía garantizaba la victoria en la gue a. Como se explica en el Códice Mendoza, lo utilizaban principalmente log guer eros de las ciudades de los márgenes del lago de agua dulce de Xochimilca un lugar de abundantes flores, por lo que las mariposas debían ser cuntio as. ${ }^{132}$ Pese a este breve análisis no es fácil adivinar cuál fue la intención de artrsta al incluir a la mariposa aquí, es muy probable que simplemente quisier recrear parte de la naturaleza que componía el monte sagrado o tal vez furero an-canto semántico a la muerte.

¿Niños en hornacinas vegetales?

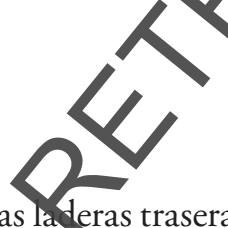

Por último, señalemos que en las laderas traseras de la montaña el orfebre introdujo, en tres ocasiones, a ni ros le corta edad, que aparentemente se encuentran dentro de hornacinas almedradas realizadas con elementos vegetales, palmas y flores (figs. I5a-c). Esán ubicados cerca o al lado de las corrientes de agua y en o próximos a las arista traseras de la montaña. Ahora habríamos de dilucidar quiénes son estonines por qué el orfebre los ubica ahí. Aunque no encontramos una xp icaci $n$ concluyente sobre la presencia de los infantes, sí podemos aventu ar algunas hipótesis extraídas de su composición, su disposición en la parte trasen de la cruz, y su inserción en nichos vegetales. Todo ello invita a pensar qu podría tratarse de niños ofrecidos a los montes. Michael Graulich cuenta que en la tercera veintena de la estación lluviosa se realizaban unos ritos dediódos a los dioses de la lluvia que incluían sacrificios infantiles para agradecernor sus dones y para obtener las últimas lluvias, siempre imprescindibles

I30. Sahagún, Historia general de las cosas de Nueva España, 748.

I3I. Seler, Las imágenes de los animales, 302.

132. Kurt Ross, Un inestimable manuscrito azteca, el Códice Mendoza (Barcelona: Serbal, 1984), 42. 
DOI: http://dx.doi.org/10.22201/iie.18703062e.2014.105.2530

I74 GARCÍA BARRIOS - PARADA LÓPEZ DE CORSELAS
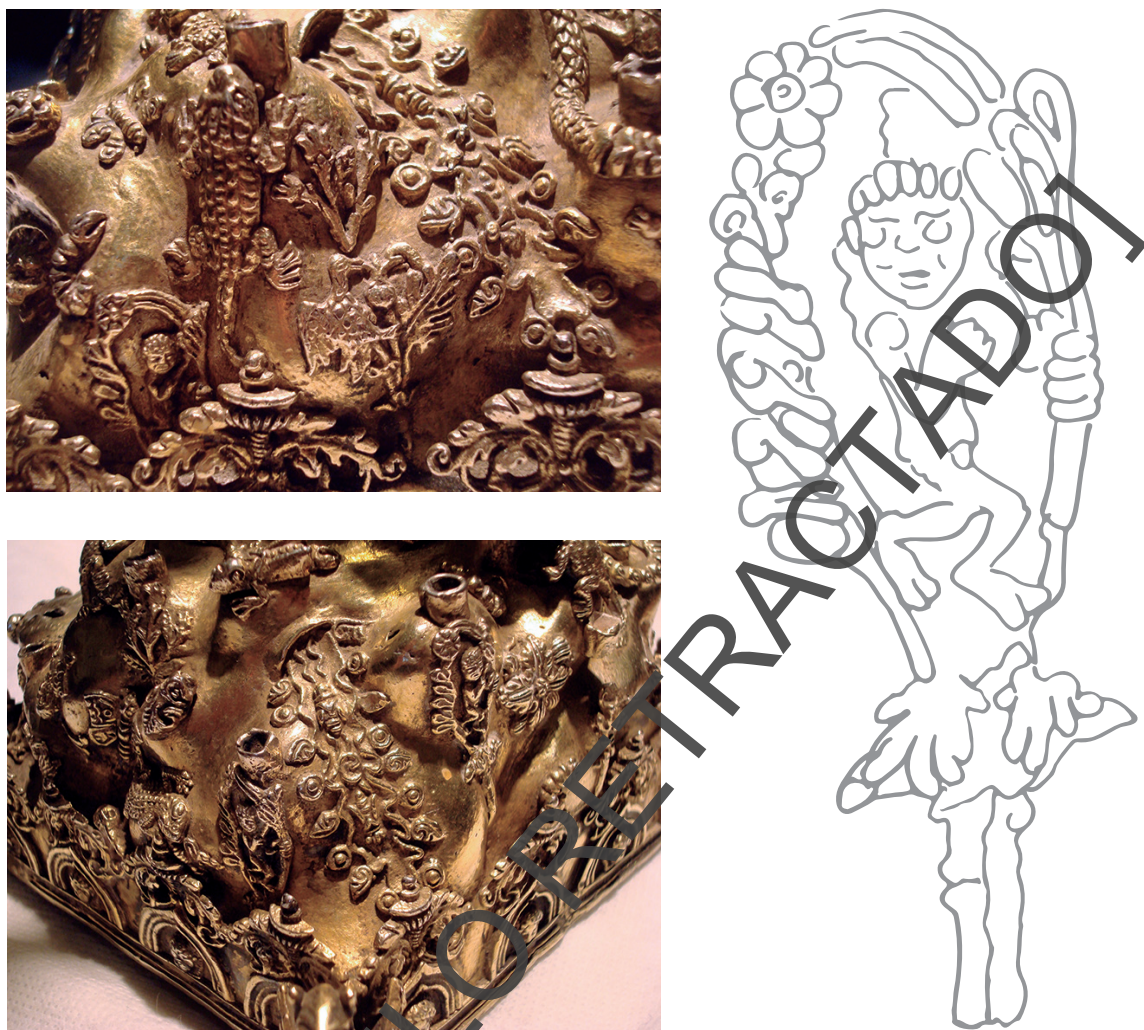

I 5 a y b). En las vertientes posterro res de la montaña se encuentran tres niños dentro de hornacinas vegetales; c) dibujo: Migut Moreno Rodríguez.

para lograr u. bueira cosecha. ${ }^{\mathrm{I} 33}$ También se sacrificaban niños en marzo y
abril, antes conmienzo de las lluvias. Fray Toribio de Benavente explica que: una 2 en el ańo cuando el maíz estaba salido de obra de un palmo, en los pueblos que hía señores principales, que a su casa llamaban palacio, sacrificaban un niño y unavina de edad de hasta tres o cuatro años; estos no eran esclavos, sino hijos de principales, y este sacrificio se hacía en un monte en reverencia de un ídolo que decían que era el dios del agua que le daba la pluvia, y cuando había falta de agua le pedían

133. Michael Graulich, Fiestas de los pueblos indigenas. Ritos aztecas. Las fiestas de las veintenas (México: Instituto Nacional Indigenista, 1999), 265-266. 
a este ídolo. A estos niños inocentes no les sacaban el corazón, sino degollábanlos, y envueltos en mantas poniánlos en una caja de piedra como lucillo antiguo, y dejábanlos así por la honra de aquel ídolo. ${ }^{\mathrm{I3} 4}$

Según fray Bernardino de Sahagún las víctimas eran niños de pechô recién nacidos que eran comprados a sus madres. ${ }^{35}$ Se llevaba a los nif os en certejo, sobre literas hasta el templo. El día de la fiesta se les condtand sacrificio adornados con plumas verdes, collares y brazaletes de jadu tenían el rostro manchado de hule. Se les sacrificaba en montañas sagr atanen santuarios ubicados en éstas. Estos cerros sobre los que se asentabz los femplos a los dioses de la lluvia están sobre cuevas por las que se accedía a inframundo, repleto de agua y riquezas, como el paraíso terrenal, conócido como Tlalocan.

Broda explica que en el ritual mexica los sa rificios de niños ocupaban un lugar central. ${ }^{136}$ Se hacían desde el mes xvi Aten zztli hasta el Iv Huey tozoztli para provocar la caída de la lluvia y fortalecent crecimiento de la planta del maíz. Como describe Sahagún, ${ }^{137}$ la fie ta mús importante se celebraba en I Atlcahualo, que correspondía al mes de febrero. Entonces, en siete lugares sagrados de la cuenca de México, los mexic s scrificaban niños a quienes cargaban los sacerdotes hasta los cerros de a montañas. Los rituales terminaban con las primeras lluvias al comienzo del nos de mayo. También Durán dice que se elegían niños de 6 o 7 años y ae sc les transportaba en literas muy aderezadas ante la figura del dios Tláloc, dode eran sacrificados, al son de bocinas, caracolas y flautas, por los mismos cerdotes de este ídolo. ${ }^{138} \mathrm{El}$ fraile, más adelante, explica que los niños sacrifica os representaban al cerro mismo, a los tlaloques, o dioses de la lluvia y tropio maíz. Los niños sacrificados tenían un papel importantísimo en la nadyración de las mazorcas. Eran un contrato entre los dioses de la lluvia los tombres, ya que gracias a estos sacrificios los mexicas obtenían la lluvia necesal para el crecimiento del maíz, por eso se llamaban nextlahualli, "la le da pagada". En la cuenca de México, el santuario más grande conocido se ancuentra en el cerro Tláloc, a una altura de 4 I $20 \mathrm{~m}$, lugar donde se coldrában los últimos sacrificios al comienzo de las lluvias, a principios

I34. Benavente, Historia de los Indios de la Nueva España, 35.

135. Graulich, Fiestas de los pueblos indigenas, 269-270.

I36. Broda, "Ritos mexicas en los cerros de la cuenca", 297.

137. Broda, "Ritos mexicas en los cerros de la cuenca", 298-299.

138. Fray Diego Durán, Historia de las Indias de Nueva España e Islas de la Tierra Firme, Biblioteca Porrúa de Historia, 36, t. I, cap. VIII (México: Porrúa, 2006), 83-84. 
DOI: http://dx.doi.org/10.22201/iie.18703062e.2014.105.2530

I76 GARCía BARRIOS - PARADA LÓPEZ DE CORSELAS

de mayo. Las ruinas del templo y su calzada de 120 metros están todavía en buen estado. ${ }^{\mathrm{I} 9}$

Con estos datos sería fácil especular con la idea de que los infantes reproducidos dentro de hornacinas vegetales en las laderas del monte de la cruz del altar fueran en realidad niños sacrificados. Esta idea encajaría perfectamonte dentro del concepto de montaña sagrada, con el sacrificio de niños pa los lio ses, ya que es el acto propiciatorio más antiguo de Mesoamérica pan solicitar la lluvia. Estos datos presentan concepciones importantísimas par en ender la sustitución del Monte Gólgota por la montaña sagrada mesoa reicana, que se exponen más abajo. Pero si observamos la disposición de los niñ s, advertimos en su mano izquierda una palma que forma parte de la hornacina vegetal en la que están envueltos. En los tres casos se repite este modelo, słijetan con la mano una palma, que bien podría reproducir el emblema en en en catolicismo se representa el martirio. Como sugirió Mario Humerto Ruz al describirle la pieza, existía la posibilidad, por las palmas que uietaban, que fuesen los primeros mártires del Nuevo Mundo, los niños partire de Tlaxcala, acontecimiento que ocurrió entre 1527 y I529. El ma tirio de estos tres niños fue recogido por varios frailes en sus crónicas, entre ell f fy Gerónimo de Mendieta. ${ }^{140}$ Sin profundizar demasiado, se extrae d la lescripción del fraile que a tres niños de edades comprendidas entre los doce y os quince años se les martirizó por haber acogido la fe católica. El primero, Cristóbal, nació aproximadamente en I515, era el hijo mayor y predilecto al calique de Atlihuetzía, en Tlaxcala. Enseguida se bautizó y predicaba consantemente a su padre y a sus vasallos. Sin embargo, su padre seguía con sureligón, así que el niño, tal y como le indicaron los frailes, comenzó a quita romper los ídolos de su padre, quien al enterarse lo mató a golpes en I52 Dos años después del martirio de Cristóbal, llegaron a Tlaxcala dos frailes que colicitaron también a dos niños para que les ayudasen con la evangelizacion. Así, los niños Antonio — nieto del heredero del señorío-y su criado unde Tizatlan, empezaron a ayudar a los frailes y a entrar en las casas de los ndígenas para acabar con los ídolos, que rompían inmediatamente. Compapunta Escalante, ${ }^{\mathrm{I} 4 \mathrm{I}}$ en Tlaxcala hubo quemas públicas de códices y objetos reigiosos, y en el valle de México, pesquisas inquisitoriales, ordenadas

I39. Johanna Broda, "Ritos mexicas en los cerros de la cuenca", 297, 299 y 302.

I40. Fray Gerónimo de Mendieta, Historia eclesiástica indiana, vol. I (México: Cien de México, 1997), 388-397.

I4I. Escalante, Los códices, 23. 
por fray Juan de Zumárraga, para tratar de localizar a quienes todavía practicaban ritos y ceremonias de la antigua religión. En Cuauhtinchan, Puebla, dos nativos atraparon a los niños cuando destrozaban a los ídolos y los mataron a palos en I529. En la actualidad, estos niños son beatos y probablemente su martirio le sirvió al orfebre como símbolo para sacralizar a esa montaña

También es posible que los frailes, en caso de haber sido lo com tertes, indicasen al orfebre que incluyese en el Gólgota a estos niñonarires para reforzar la simbología que, ya en sí misma, implica el lugar do mar irio y resurrección de Dios. Por otro lado, no hay que descartar que aresonnos, quienes alcanzaron la muerte por la defensa de su fe y su Dios, os vi ra o entendiera el orfebre como nińos sacrificados a un ser divino, tal y comova costumbre hacer en la religión nativa. Lo que, de paso sería una bena strategia para "hacer pasar" más fácilmente la pieza bajo los ojos de hortodoxia cristiana y el celo vigilante de los frailes, tal y como sugiere Mario numberto Ruz. ${ }^{\text {I42 }}$

Los niños de Tlaxcala también podían abersetvido como signo identitario y de reafirmación de aristocracias indíg as, omo sucede con el cura cacique del siglo xviII Ignacio Faustinos MaAhcatzm y Calmecahua, descendiente de los reyes de Ocotelulco, familia des ad por su colaboración en la conquista cortesiana. El religioso encar on ciclo pictórico en el cual vinculaba escenas religiosas con su familia y pati. Para poder colocarlo en su iglesia de San Simeón de Yehualtepec se ncaró de pedir permiso a las autoridades religiosas de Puebla mediante una cu dadosa memoria — la cual nos informa de lo peliagudo de la petición - ánde e incluían acuarelas con las escenas propuestas. ${ }^{\text {I43 }}$ Éstas eran la aparición ay la Virgen de Ocotlán al indio Juan Diego; la aparición del arcángel san Aigtedel Milagro al indio Diego Lázaro; la predicación del apóstol sant TCmás en Tlaxcala, con la introducción de la devoción a la Santa Cruz; y e matirio de los niños de Tlaxcala. Tal vez estos elementos - concretamente la devoción por la Santa Cruz, el papel de los niños de Tlaxcala y la reafirnacón_local - o contenidos semejantes que seguían vivos incluso en el sigle Xvis tuvieron un papel importante en los mensajes que en el siglo XVI se quer 1 presentar mediante la cruz de Palencia o de conjuntos como el citado clautro de Cuauhtinchan. Casualmente, fueron principales de Cuauhtinchan

I42. Comunicación personal, 2013.

I43. Véase Jaime Cuadriello, "Las glorias de la república de Tlaxcala: patrocino artístico y genealogía indocristiana”, en Patrocinio, colección y circulación de las artes, ed. Gustavo Curiel (México: Universidad Nacional Autónoma de México-Instituto de Investigaciones Estéticas, 1997), 195-213. 
DOI: http://dx.doi.org/10.22201/iie.18703062e.2014.105.2530

I78 GARCía BARRIOS - PARADA LÓPEZ DE CORSELAS

quienes mataron a Antonio y Juan en I529; las autoridades indígenas de la misma localidad se apresuraron, tres años después, en demostrar su fervor católico suplicando al guardián de Tepeaca que enviase algún predicador para convertir a los otomíes y popolacas que habitaban en una aldea próxima. ${ }^{44}$

\section{La cruz de Palencia en una encrucijada de dos religion}

Después de estudiar con detalle la pieza, los elementos que la conerman y la estratégica disposición de los diferentes elementos estudiad §, po femos afirmar que el maestro orfebre era conocedor tanto de la iconografía cistiana como de las tradiciones mexicas. Suponemos que el trato con us d pses prehispánicos los adquirió, lógicamente, por herencia familiar y dicion oral, y no hay que descartar que hubiese tenido la oportunidad de asis r r rituales en los cuales hubiera sacrificios humanos, como obligaban as and costumbres religiosas. Parece que estuviese, como sugiere esta eza, nepantla, tal y como hemos explicado citando a fray Diego Durán. Dicho éstimonio es muy esclarecedor para entender qué ocurría en ese momo el pensamiento indígena. Fray Toribio de Benavente, más conocid o Motolinía, asienta a este respecto:

desde ha poco tiempo vinieron atacir a los frailes cómo escondían los indios los ídolos y ponían en los pies de las cru es, o n aquellas gradas debajo de las piedras, para allí hacer que adoraban la crez y adorar al demonio, y querían allí guarecer la vida de su idolatría. Los ídolos qu Iondios tenían eran muy muchos y en muchas partes, en especial en los templos ofe sus demonios, y en los patios, y en los lugares eminentes, así como bosques, randes cerrejones, y en los puertos y montes altos, y en los caminos, a doquiera que raera algún alto o lugar gracioso, o dispuesto para descansar; y los que pasan echaban sangre de las orejas o de la lengua, o echaban un poco de inciense do lo que hay en aquella tierra, que llaman copalli. ${ }^{145}$

Cierto due estos ídolos, a los que se les destruyó, son los que se dise aro en el monte que sustituye al Gólgota, sin embargo, debemos advertir al leoror sobre la probabilidad de que muchos de los seres que fray Toribio de Benavente clasifica como ídolos, no lo fuesen realmente. No hay que olvidar que al igual que al indígena le costó entender la nueva religión traída por los

I44. Escalante, "El patrocinio del arte indocristiano", 222-224.

I45. Motolinía, Historia de los indios de la Nueva España, 26. 
DOI: http://dx.doi.org/10.22201/iie.18703062e.2014.105.2530

conquistadores, centrada en la figura de la Santísima Trinidad, para los evangelizadores fue igual de complicado comprender la religión prehispánica. Resulta importante ser cautos ya que muy posiblemente todos estos "ídolos", nombrados por el fraile, no sean seres con carga sagrada, aunque de igual modo ayuda a comprender los elementos que fueron elegidos por el orfebre de estemonte sagrado para sustituir o equiparar al Gólgota. ${ }^{46}$

\section{¿Por qué el artífice sustituye al Gólgota por la montaña sagrada mesoameric ha?}

La composición de esta obra, una cruz con una iconogr fía totalmente cristiana, sin ningún elemento ajeno, y una montaña resoamericana con iconos indígenas, indican que el orfebre era conocedor do a abas religiones, la suya tradicional y el recién llegado catolicismo, y pu iener varios los motivos por los que no construyó un monte Gólgota de Ruras calaveras sino una montaña con una gran carga simbólica que exponemos a continuación. Y es que este monte sagrado era esencial en la concepción clig osa indígena para mantener el orden del cosmos y el bienestar del puebo se puede pensar que la intención última del artista al colocar a Cristo crucificado, a Dios Padre bendiciendo y a María Virgen, pudo deberse al meno a ans motivos.

Como primera hipótesis se antea que el orfebre quiso dar mayor sacralidad a este emblema católiço, Crigko crucificado, cuyo significado teológico conocía muy bien, pues los fran iscanos llevaban años evangelizando en aquellas tierras. La presencizede elementos indígenas en el monte Gólgota potencia y refuerza el a en ecim iento del sacrificio y muerte del Hijo de Dios, al ubicarle como axis und o árbol primigenio, arriba de la montaña mesoamericana. Por otro lado, a indusión en la cara frontal de la montaña de una escalera sinuosa hasta el ped a 1 madero, recuerda a esas grandes avenidas y calzadas que llegaban hasta los mplos situados en lo alto de las cimas de la montañas de la cuenca de Méx of, en concreto la que describe fray Diego Durán que llegaba hasta el monte Nároc, donde todos los señores principales de la cuenca de México subían a presenciar el sacrificio, pero también pueden aludir a las escaleras por las que al menos tres veces se cayó Jesús camino del Calvario. Si recordamos la pasión de Cristo, debemos imaginarlo subiendo a ese monte, cargando con su cruz para 
DOI: http://dx.doi.org/10.22201/iie.18703062e.2014.105.2530

ser sacrificado en lo alto de la montańa. Este hecho, la muerte del Hijo de Dios en el cerro sagrado, debió verse como el máximo exponente de sacrificio que complacería a los dioses habitantes del interior del monte, asegurándose las lluvias y buenas cosechas. Igualmente, el Gólgota es el lugar del martirio, de muerte y resurrección y la presencia de los niños como mártires y sacrificados âlavez en su concepción mesoamericana debió reforzar más aún la sacralidad de Jesús No olvidemos que no sólo incluye elementos semánticos que refueran idea en la base de la cruz, sino que ubica a Cristo con sus "padres", "antepa ados" o "ancestros", Dios Padre y la Virgen María, un concepto de vero pad relevancia para la existencia indígena.

Asimismo, esta montaña sagrada posee las mismas cualidades sacras que el Gólgota, por ser ambas lugar de sacrificio de dioses o pa los lioses. Posiblemente, para el orfebre esta montańa era el Tlalocan, la mpada del dios de la lluvia, el lugar de la abundancia, tierra de riquezas o "paraíso te renal". Tlalocan también es el lugar de la muerte ${ }^{\mathrm{I} 47} \mathrm{y}$ en donde se trasmit el poder a los fundadores dinásticos. ${ }^{I 8}$ Tláloc es el gobernante de ese espa mitico, quien preside el principio y el fin de los reinos. Para López Austin, Tlalocarestá en relación "con la circulación de lo invisible, de los cursos que sigun las sustancias sutiles que dan naturaleza a los seres del mundo [...] so si ios de origen y destino de estas sustancias sutiles que podemos llamar almas fuerzas divinas y que se encuentran en el interior de las criaturas". 49 Fsto s claro en las fuentes que hablan de la constitución de los hombres.

Como segunda hipótess se propone que el orfebre conjugase las dos imágenes, no con la intención ye lusionar ambas religiones en una, sino con la de potenciar la trascendenciay arga espiritual de cada una de ellas individualmente, porque una ara on 1 que había nacido y crecido, y la otra era la que desde hacía años le hobía ido impuesta y tal vez por él admitida. Opuestas y complementarias, un principio que todavía prevalece en el pensamiento indígena de América, ue annque cueste aceptarlo, estos pueblos son al día de hoy en su fe y sus creencs, totalmente cristianos, y totalmente indígenas. Así, la simbología que priprica la imagen de Cristo clavado en la cruz, no evoca únicamente su sacnficio, ${ }^{150}$ sino que también es el emblema de la redención y salvación de

I47. López Austin, Tamoanchan y Tlalocan, 9.

I48. Contel, "Tlallocan en los diálogos de I524, 4-5.

149. López Austin, Tamoanchan y Tlalocan, I7-18.

I50. Para los indígenas este aspecto seguro tuvo gran valor por el sacrificio en sí mismo, aunque a la vez produjo gran sorpresa, ya que ellos, por lo general, tenían por costumbre sacri- 
la Humanidad. Adquiere sobre este Gólgota mesoamericano, paraíso terrenal del pueblo mexica, un carácter sagrado y único que le convierte en árbol de la vida y señor del tiempo; el tiempo de Cristo, el actual, en el que reinará hasta su próxima venida, tal y como predicaron los frailes por aquel entonces. El sentido sacro y de sacrificio de sangre podría estar reforzado por medio de parâlismos con Quetzalcóatl y los niños "sacrificados" de Tlaxcala. El precio o valor ce la sangre se enfatizaría no solamente en el crucificado, sino ademźsan tagran flor junto a uno de los niños, así como posiblemente por medio do las lores cactáceas que recordarían las connotaciones sacrificiales de plan as amo la biznaga, a las cuales tal vez haría alusión la forma globular de cris al donde apoya la cruz, rodeada de flores que también parecen cactáceas representadas con su raíz, similares a las del folio 4 del Códice Boturini, donde se re rese ta un sacrificio humano realizado sobre dichas plantas; citemos a este epecto la similitud con la peana de la cruz atrial de Chimalistac, que Escalant interpreta como agrupación de las plumas - o incluso manojos de hier as aon las que en los rituales prehispánicos se recogía la sangre del sacrifjo humano para su incineración ritual, aunque opinamos que su forma se asemeja más a una cactácea. ${ }^{\mathrm{III}}$ Esta planta se representa claramente en la base au co atrial de Nonoalco, obra en la que figuran además tres flores abier as angrantes que aluden a las heridas "sacrificiales" de Cristo. Todos estos ejemilos pueden compararse también con el cacto representado sobre el ex remp izquierdo de la montaña-cueva de la Historia Tolteca-Chichimeca (figs. Io -f) En cualquier caso, en la cruz de Palencia observamos indicios de asocraciones entre las fórmulas alusivas al sacrificio humano prehispánico, y al de Cnyto.

Recordando estimenios como el de fray Toribio de Benavente, ${ }^{\mathrm{IS2}}$ podría pensarse qua la gosib)e intención del artífice fue la de disimular u ocultar "ídolos" en la caz. En primer lugar, hemos de decir que los indígenas no siempre harían esto con intención de ocultar nada, sino más bien de sacralizar y completar on sus propios elementos aquello que el cristianismo les ofrecía. ¿Al día de hoy lo indígenas, sin riesgo de persecuciones, no siguen "ocultando" o colo-

fican eres humanos para sus dioses y no que éstos lo hiciesen por nosotros. Aunque contamos con un Caso excepcional, como el de Nanahuatzin, quien se arroja voluntariamente al fuego de modo que se sacrifica a sí mismo y se convierte en Quinto Sol, como Cristo que se sacrifica para redimir el pecado del Hombre y entre algunas culturas meseoamericanas se le identifica con el Sol.

I5I. Escalante, "Cristo, su sangre y los indios", 72.

I 52 . Véase n. I Io. 


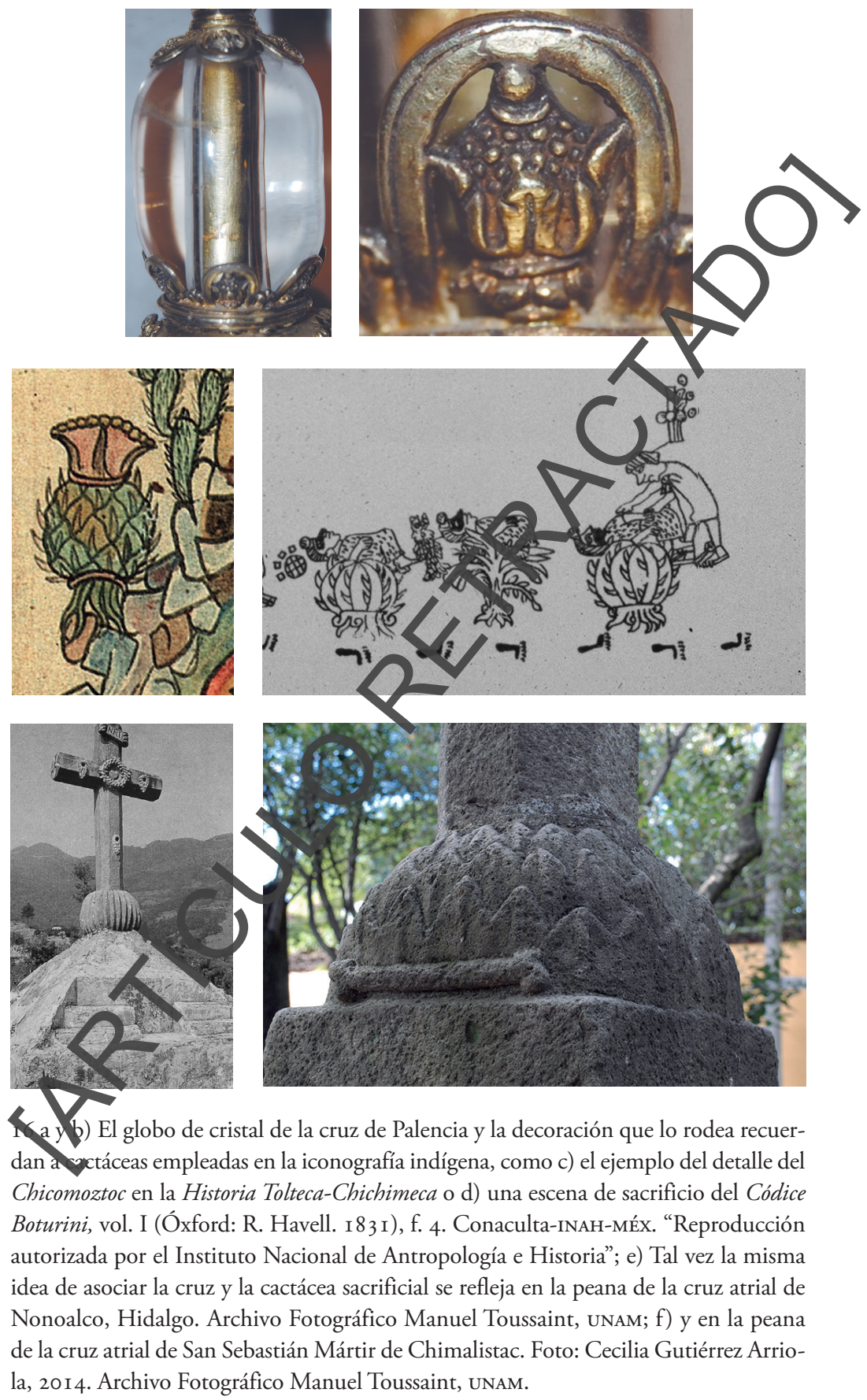


cando emblemas suyos, como el jaguar, en los altares? ¿Acaso el altar cristiano en sus orígenes no necesitaba estar legitimado por las reliquias de un mártir o un santo, una vía de comunicación con lo divino semejante a los "ídolos" indígenas? El fenómeno se nos antoja más complejo que la interpretación superficial de fray Toribio. Por otro lado, es posible que, teniendo en cuenta que a ese tipo de prácticas no las vieran con buenos ojos los evangelizadores com dicho religioso, tal vez se llegó a una solución de compromiso; piénsesentaristianización de la montaña sagrada a base de elementos como los niños nárty es de Tlaxcala y Cristo como exponente máximo de sacrificio, pues sto montaña sagrada no tiene sentido si no está Cristo en ella; es decir, en obr que nos ocupa es Cristo quien da sentido a todo el programa salvífico

I53. Como se trata del único ejemplar conservado hasta dondesabemos, es imposible establecer comparaciones y pudo ser una fórmula compleja que no go ara de gran difusión. No obstante, entre los objetos entregados al papa en I 533 en Bolny se encontraba una cruz de calcedonia que medía medio pie de alto colocada sobre un mon alizado en alabastro finísimo, objeto tal vez traído por Domingo de Betanzos (Laura Lan ancichMinelli, "From the New World to Bologna, I533. A gift for Pope Clement VII and Bologese collections of the sixteenth and seventeenth centuries", Journal of the History of C Ille tions, núm. 24.2 [2012]: I45); Davide Domenici y Laura Laurencich-Minelli, "Dominge a Bo ros' gifts to Pope Clement VII in I532-I533: Tracking the Early History of some Mr ir an Objects and Codices in Italy", Estudios de Cultura Nábuatl, núm. 47 [enero-junio de 2014]: 169-209. Por la fecha tan temprana, el monte podría contener elementos semejantes de cruz de Palencia, pero hasta que la pieza no se localice no sabremos con exactitud cómo es su composición. El ejemplo tipológico e iconográficamente más próximo a la cruz de Palencia sería la citada cruz-relicario con Calvario con calavera de cristal de roca, y estilísticamente ruz de Fregenal. Otra cruz de altar similar, pero carente de cualquier rasgo americano, re lizada en plata dorada y cristal de roca, encierra un lignum crucis y se apoya en un alvario clesnudo; se encuentra en el Museo Diocesano de Albarracín y es obra de Andrés Ma cuell _ — vecino de Zaragoza — realizada en I573-I574 (Ernesto Arce Oliva, "La platería recaco tista de la catedral de Albarracín: génesis de una colección", en Estudios de Historia dek Arm Libro homenaje a Gonzalo M. Borrás Gualis, eds. María Isabel Álvaro Zamora, Conc poón Lomba Serrano et al. [Zaragoza: Institución Fernando el Católico, 2013], I54. Como c paración meramente anecdótica podría recordarse la representación del cerro Potosí, en p de $46 \mathrm{~cm}$ de ancho, encargada en Perú por el arzobispo Diego Morcillo, datada en I7I9 y a a da como peana de la Virgen de la Caridad de Villarrobledo, pueblo natal del prelado (Lù García-Sauco Beléndez, "Maqueta del cerro de Potosí utilizada como peana. I719", en La Iglesia en América: evangelización y cultura, catálogo de la exposición, cat. 242 [Sevilla: Pabellón de la Santa Sede, 1992], 316-317) o la cruz de altar conservada en la catedral de Segovia y posiblemente de origen amalfitano, que se apoya en un monte realizado en plata en el que hay algunos elementos - como caracoles - en coral rojo. Un crucificado de tamańo inferior al natural realizado en madera policromada, con su Gólgota donde habitan diversos animales y plantas, se conserva en la catedral Vieja de Salamanca. 
DOI: http://dx.doi.org/10.22201/iie.18703062e.2014.105.2530

I84 GARCía BARRIOS - PARADA LÓPEZ DE CORSELAS

Como tercera hipótesis planteamos que el programa iconográfico de la cruz de Palencia fue una decisión consciente y asumida sin ocultamientos que podría recurrir a principios o estrategias semejantes a los del claustro del convento de Cuauhtinchan ( $c a$. I560) o el ciclo pictórico encargado en el siglo XviII por el cura cacique Mazihcatzin. Son obras que asumen su condición cristianâ pero que retoman procedimientos simbólicos de la tradición prehispánica, no spla mente buscan una adecuación religiosa frente a las nuevas autoridatan es y religiosas, sino que también investigan una fundamental legitima ción le cara a la amplia población indígena, en la que la aristocracia cacique "Draborionista" seguía siendo un elemento de poder perfectamente capacit do pra comisionar obras en las que reivindicaría sus remotos orígenes, su papel preeminente en la nueva sociedad y su apego a la religión católica, aunque fue a desde una visión propia o interesada. Cabe recordar que el citado Cencilio ue I 554 en su capítulo XXXIV establece que todas las obras debían pas. por el control estricto y vigilante de la Iglesia, lo cual nos induce a pens che cruz de Palencia es anterior o bien que no se consideró peligrosa o capol control oficial, fenómenos que no serían raros, puesto que conjuntos comol de Cuauhtinchan pudieron llevarse a cabo. No obstante la cruz de Nenga debió pasar algún tipo de control, al menos por parte de las autor adesencargadas del marcaje de la plata. \$

N. B. De forma especial queremos mostrar nuestro agradecimiento al canónigo de la catedral de Palenci AMador Valderrábano por todo el apoyo prestado para poder llevar a cabo esta investig cron. AsImismo, a Mario Humberto Ruz por sus sugerencias tan valiosas y a Cristina Es r s Martín (Departamento de Historia del Arte II, UCM) por sus indicaciones bibliogr No queremos pasar por alto tampoco las ventajosas aportaciones de los profesor de Departamento de Antropología de América de la Universidad Complutense de Madrid, Manuel Gutiérrez Estévez, Alfonso Lacadena García-Gallo, José Luis de Rojas, así como las de María Teresa Uriarte Castañeda de la Universidad Nacional Autónoma de México, y Enrique Florescano del Instituto Nacional de Antropología e Historia, así como el apoyo en la realización de los dibujos Miguel Moreno y sus comentarios sobre los concilios mexicanos. Agradecemos también la ayuda de Albert Estrada Rius, del Gabinete Numismático del MNAC.

* Todas las fotos salvo que no se especifique de otro modo son de los autores. 